\title{
A Review on the Archaeological Chemistry of Shellfish Purple
}

\section{Ioannis Karapanagiotis $\mathbb{D}$}

Department of Management and Conservation of Ecclesiastical Cultural Heritage Objects, University Ecclesiastical Academy of Thessaloniki, 54250 Thessaloniki, Greece; y.karapanagiotis@aeath.gr; Tel.: +30-2310-301784

Received: 24 May 2019; Accepted: 17 June 2019; Published: 29 June 2019

\begin{abstract}
Shellfish purple, also known as Tyrian purple and royal purple, has a long history, which has been revealed and documented in recent years through valid physicochemical studies using sophisticated techniques. The aim of the work was to summarize the conclusions of these studies and to describe the results of two unpublished investigations regarding the (i) identification of shellfish purple in a textile (4th century BCE) from ancient Macedonia and (ii) dramatic effect of the dyeing conditions on the composition of the purple dye. Moreover, a critical discussion is included about the discovery of the shellfish pigment and dye based on the available scientific evidence. Previously published reports describing the identification of the shellfish colorant in objects of the cultural heritage were carefully summarized. Shellfish purple was not used only as colorant, but it served other purposes as emphasized in this review. In particular, examples for the use of shellfish purple in medicine, grave goods and fillers and plasters in walls, were described. Examples of materials and methods that were used in the past to produce "fake" purple, imitating the aesthetic result of the valuable royal marine material were summarized. Finally, the solubility of indigoids was discussed using modern approaches of physical chemistry.
\end{abstract}

Keywords: purple; shellfish; mollusk; Tyrian purple; indigo; pigment; dye; cultural heritage; HPLC

\section{Introduction}

Identification of the materials of cultural heritage objects is important to develop and apply effective conservation strategies, which ensure the preservation of the valuable historical and archaeological objects. Conservation and preservation are probably the most important conditions towards a sustainable market for cultural heritage, along with appropriate policies aiming at promoting the human civilization through the multidisciplinary area of archaeometry and other disciplines [1]. Moreover, the characterization and identification of cultural heritage materials leads to useful insights regarding the technological skills of civilizations and reveals economic, social and historic aspects [2]. For these reasons the application of physicochemical methods and instruments to archaeological research has increased substantially over the last half-century and today represents a major methodological subfield within archaeological science [3].

Ever since the beginning of human existence, humans made use of materials to color virtually everything they used or had: Bodies, caves, pottery, sculpture, stone structures, parchment, paper, clothing and other textiles [4]. The important role of color in human civilization becomes dominant for painting art and textiles. The former is essential for human nature, as evidenced for example by the Lauscax cave paintings, dated from about 17,000 BCE and the hundreds of other paleolithic cave paintings e.g., in Altamira, Chauvet and Cáceres. The astonishing findings of abalone shells that were used to hold ochre mixtures 100,000 years ago suggest that pigments were utilised from the very early days [5]. The vital, timeless and universal power of painting and, more general, pictorial art is 
evidenced in many different ways. For example, icons have been used for centuries by the Orthodox Church as a window to communicate with the unseen divine reality whereas the Pioneer plaques are pictorial messages for potential extraterrestrial life. Organic materials such as textiles and their colorants (dyes) are sensitive to degradation effects developed through ageing. Consequently, early known-identified use of dyes dates back to at around 6000 years ago [6], which falls short compared to the iron and manganese pigments found in the aforementioned prehistoric caves.

Among the various colorants, which have been used since the prehistoric times, shellfish purple originating from marine mollusks holds a prominent position [7-9]. Shellfish purple (in Greek, porphyra $=\pi \rho \rho \varphi v ́ \rho \alpha$ ) is known also as Tyrian purple, because of the significant deposits of shells found in the area of Tyre and the important role of the purple dye in the Phoenician history. The material is also known as royal purple and imperial purple, as the expensive purple-dyed textiles were status symbols. Shellfish purple is connected with the incredible story of tekhelet, the elusive sky-blue color mentioned throughout the Bible and the clothing of emperors and high priests in civilizations, which had scattered all around the Mediterranean basin.

The goal of this review is to summarize the current state of the art provided by the Natural Sciences for the shellfish purple in archaeology. Examples of historical written sources are briefly presented; biological mollusk sources and the chemical composition of shellfish purple are described. Critical discussions are included associated with the discovery of the shellfish pigment and dye based on the available scientific evidence. Previously published reports describing the identification of shellfish purple in objects of cultural heritage are carefully summarized, revealing the pros and cons of the physicochemical instruments employed for analytical purposes. Emphasis is placed on the results of shellfish purple in the prehistoric Aegean. Two unpublished studies are included (i) describing the identification of shellfish purple in a textile from ancient Macedonia and (ii) demonstrating the dramatic effect of the dyeing conditions on the composition of the purple dye. Shellfish purple was not used only as a paint and dye, but it served other purposes as described in the present review. Materials and methods that were used in the past to produce "fake" purple, imitating the aesthetic result of the valuable imperial marine material are discussed. Finally, the solubility of indigoids is discussed using modern approaches of physical chemistry.

\section{Historical Written Sources and Legends for Shellfish Purple}

The first inscription referring to the royal color is revealed in Amarna letters, dated to the 14th century BCE, in which blue-purple wool objects are described [10]. Another important written source comes from the Mycenaean Linear B clay tablets of Knossos dated to the 13th century BCE [11]. The masculine (po-pu-re-jo) and the feminine (po-pu-re-ja) adjectives are cited in tablets KN X976 and KN L474, respectively [11]. According to the Acts of the Apostles (Chapter 16), Lydia of Thyatira, who was baptized by St. Paul and is the first documented convert to Christianity in Europe, was in the purple-dye trade. Purple produced from mollusks is mentioned several times in the Bible as well as by Homer, Aristotle, Herodotus, Aeschylus and several others [12]. An impressive written example for the use of purple in Byzantine times is the inscription of the mosaic of the Byzantine Emperor, John II

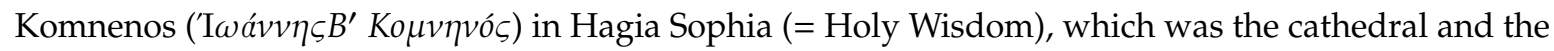
spiritual center of the Byzantine empire, as it was the Parthenon for Athens, which was dedicated to the Goddess of Wisdom, Athena. The mosaic in Hagia Sophia is dated to the 12th century CE and the inscription reads: "John faithful in Christ God, emperor of the Romans the Komnenos and king born in the purple".

The history of shellfish purple is full of legends with the most famous being the one describing the discovery of Murex shellfish by Hercules' hound. The scene is represented in the exergue of coins with the ambrosial rocks $[13,14]$, as well as in paintings, such as the oil on panel artwork by the 17th century Flemish master Peter Paul Rubens [8]. Murex shells have been represented in various objects since antiquity, as shown for instance in the Geek krater and coin of Figure $1[15,16]$. 


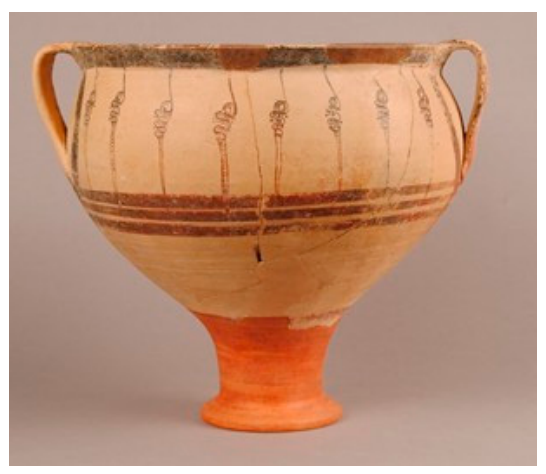

(a)
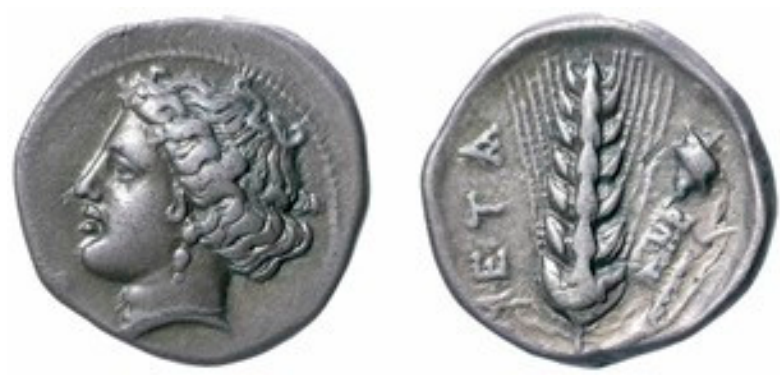

(b)

Figure 1. (a) Pottery krater painted with red bands and row of parallel murex shells (13th century BCE). (b) Silver coin with the Head of Demeter (observe) and barley-ear with murex (reverse; 4th century BCE). Both objects were found in Greece $[15,16]$. (C) The Trustees of the British Museum. Shared under a Creative Commons Attribution-NonCommercial-ShareAlike 4.0 International (CC BY-NC-SA 4.0) license.

\section{Biological Sources and Chemical Composition}

Shellfish purple originates from marine mollusks of the Muricidae family, such as Hexaplex trunculus L. (Murex trunculus), Bolinus brandaris L. (Murex brandaris) and Stramonita haemastoma (Thais haemastoma). These three species live in the Mediterranean basin where the use of the purple pigment/paint in prestigious archaeological findings has been revealed. In the Aegean Sea, M. trunculus is the most abundant followed by M. brandaris and finally T. haemastoma species. However, it should be noted that the mollusk populations have been affected by the recent effects of sea pollution and global warming [17]. Surprisingly, T. haemastoma mollusks once described in the taxonomic literature as common in the Levant basin were not found in a recent survey [17]. In the same investigation, a decrease in the population of M. trunculus was reported. These observations are schematically presented in Figure 2.

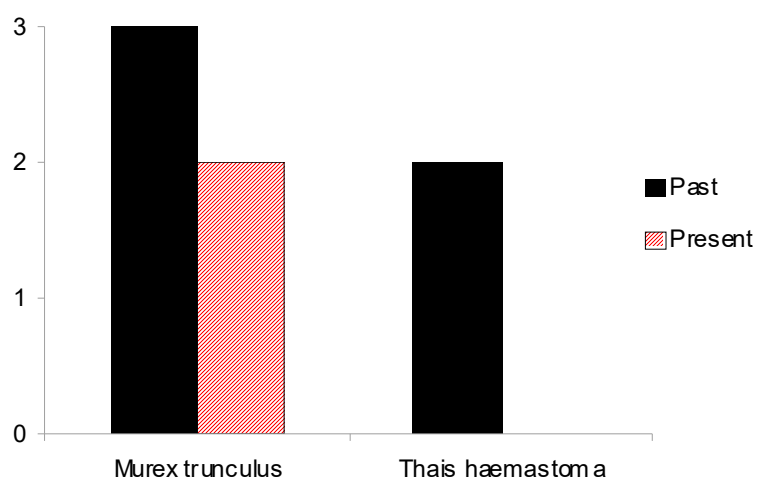

Figure 2. Past and present abundance categories for Murex trunculus and Thais haemastoma populations in the Levant basin [17]: $0=$ not found; $1=$ rare; 2 = common; $3=$ very common.

Photographs of M. trunculus mollusks, which were collected in the Thermaic (Thessaloniki) gulf in the Aegean Sea, are shown in Figure 3a. The coloring compounds do not exist in the living mollusks, but they are produced by precursors that are called chromogens. The latter are present in hypobranchial glands of the mollusks and undergo spontaneous chemical reactions under exposure to light and air thus yielding to the coloring components of shellfish purple $[9,18]$. For example, the reaction series for the conversion of tyrindoxyl sulfate (precursor) to 6,6'-dibromoindigotin, DBI (coloring compound) is schematically illustrated in Figure $3 b[9,18]$. The conversion is fast and it takes about $5-10$ minutes after exposure to air and sunlight. By analogous reaction series, the other coloring compounds of shellfish 
purple are produced: Indigotin (IND), 6-bromoindigotin (MBI), indirubin (INR), 6 '-bromoindirubin (6'MBIR) 6-bromoindirubin (6MBIR) and 6,6'-dibromoindirubin (DBIR).

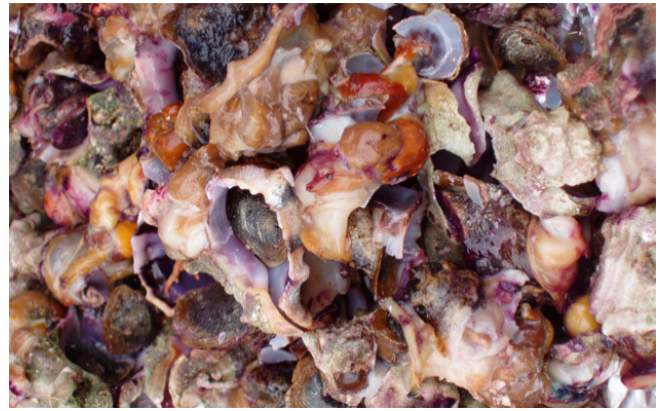

(a)

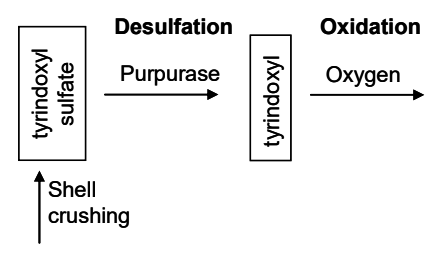

$$
\begin{gathered}
\text { tyrindoxyl sulfate (precursor) } \\
\& \\
\text { purpurase (enzyme) }
\end{gathered}
$$

Initial compounds
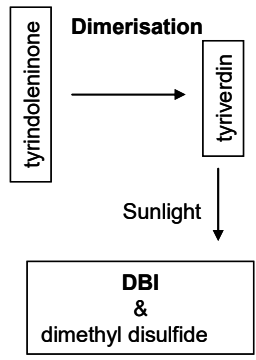

Final products

(b)<smiles>O=C1/C(=C2\Nc3ccccc3C2=O)Nc2ccccc21</smiles>

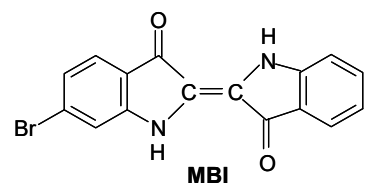<smiles>CCOC(=O)c1[nH]c2cc(Br)ccc2c1C1Nc2cc(Br)ccc2C1=O</smiles><smiles>O=C1Nc2ccccc2C1=C1Nc2ccccc2C1=O</smiles><smiles>O=C1C(=CC2NC3CCCCC23)Nc2ccccc21</smiles>

MBI DBI<smiles></smiles>

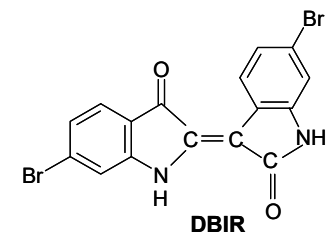

(c)

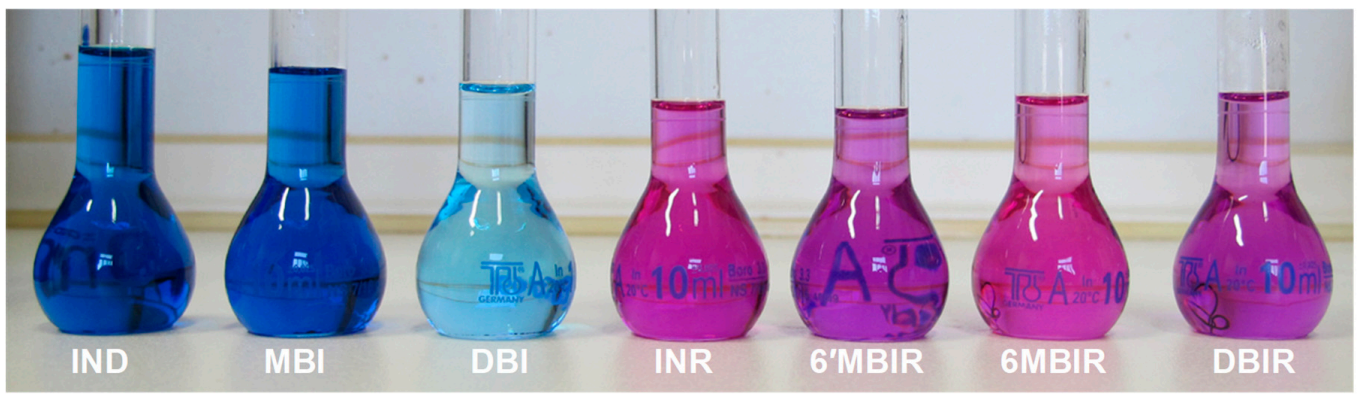

(d)

Figure 3. (a) M. trunculus mollusks. (b) Conversion of tyrindoxyl sulphate to DBI. (c) Structures of the coloring compounds of shellfish purple: Indigotin (IND), 6-bromoindigotin (MBI), 6,6'-dibromoindigotin (DBI), indirubin (INR), 6'-bromoindirubin (6'MBIR) 6-bromoindirubin (6MBIR) and 6,6'-dibromoindirubin (DBIR). (d) Solutions of the compounds in dimethyl sulfoxide (DMSO), $20 \mu \mathrm{g} \mathrm{mL} \mathrm{m}^{-1}$.

The compounds of Figure 3c were detected in extracts of $M$. trunculus [19-21] and M. brandaris [22]. However, only MBI, DBI and DBIR were detected so far in extracts of T. haemastoma. Four more analogues of brominated and unbrominated indirubins, which were detected in $M$. trunculus extracts, were not included in Figure 3c [23]. These isomers have been scarcely reported, as they were found in extremely small amounts [23]. In early reports, DBI was considered to be the marker for the identification of shellfish purple, as this was the first compound isolated from the raw purple pulp [24]. However, none of the brominated molecules of Figure $3 c$ is found in any colorant other than the shellfish purple and therefore any of these molecules can be considered as markers for the presence 
of shellfish purple. Moreover, DBI is not necessarily the most abundant component of the purple extract. Chromatographic results have shown that in some $M$. trunculus extracts, MBI is found in larger amounts than DBI [19-21].

Today, the compounds of Figure $3 \mathrm{c}$ can be produced in pure forms and in relatively large amounts following synthetic routes [20,25-27]. Photographs of standard solutions of synthesized shellfish components are provided in Figure 3d. Solutions of indigoids (IND, MBI, DBI) are bluish whereas solutions of indirubinoids (INR, 6'MBIR, 6MBIR, DBIR) are reddish. The latter are usually found in shellfish extracts in small amounts. Focusing now on the indigoids it is observed that the DBI solution has a bluish-purple color whereas the MBI and particularly the IND solutions are blue. Consequently, the color of a painted/dyed object can vary, depending on the relative composition of the fixed purple pigment/dye. For example, it was shown that wool dyed with (i) IND is blue, (ii) DBI is purple and (iii) MBI is in between blue-purple [28,29]. Microscopic and chromatographic studies in a 1500-year-old textile dyed with shellfish purple, showed that blue-purple and red-purple fibers were rich in IND and DBI, respectively [30]. In other studies on archaeological textiles, it was suggested that shellfish purple in antiquity was sometimes combined with red anthraquinones, when high proportions of IND were attached on dyed textiles [31-34]. High proportions of IND may have resulted because of the composition of the source mollusk or the dyeing conditions, as both affect the resulting color [28,29]. High proportions of IND may have resulted in purple dyes that looked too blue and therefore mixing with a red colorant was probably necessary to adjust the color and to make it look more purple [31].

\section{The Discovery of the Purple Colorant}

The origins of the purple dyeing or pigment production industry could have been in the Persian Gulf [9]. P. G. Moatsos wrote in 1932 that probably the Sumerians discovered the use of shellfish purple as a dye for textiles [35]. However, to date, there is no archaeological or scientific evidence to support this hypothesis. The earliest scientific evidence suggesting purple dyeing in the Gulf area goes back to only 3rd-5th century CE [36]. Fragments of pottery vessels used as dyed baths were analyzed revealing the presence of shellfish purple [36].

The first confirmed use of shellfish purple in wall paintings comes from the analyses of samples found in the islands of Santorini and Rhodes in the Aegean Sea [37-43]. The samples are dated to the 18th-17th century BCE. Among the findings in which the presence of shellfish purple was revealed by chemical analysis was a lump of pigment (Santorini). Chromatographic studies showed that the relative chemical composition of the pigment was similar with the compositions of purple paints removed from local wall paintings, proving indisputably the use of the pigment in the local painting art and suggesting pigment production in the Aegean in the Late Bronze Age [42,43]. The pigment was rich in chalk-aragonite and was presumably prepared by immersion of the chalk in the vat serving for the dyeing of textiles [43]. The procedure for the preparation of the pigment purpurissum, documented by Pliny the Elder [44], is reported to occur in the same dye bath, which also served for the dyeing of purple textiles [45]. It has been therefore suggested that the production of organic pigments in ancient times was probably carried out within the existing dyeing workshops using white inorganic substrates, which gave body to the purple pigment $[43,45]$. This argument is supported by the chemical results reported for samples that were extracted from a painted burial klinai and a textile fragment, both found within the same tomb, in Daskyleion (5th century BCE) [46]. The relative compositions of the shellfish purple pigment and dye used in the two objects were similar according to chromatographic results [46], thus offering support to the scenario that pigment production and dyeing were probably carried out within the same batch reactor-vessel. If this is true, then it serves as indirect evidence for the presence of a shellfish dyeing textile industry in the prehistoric Aegean where the purple pigment production has been confirmed.

The oldest textile fragments dyed with shellfish purple were found in archaeological sites in Syria and particularly in Chagar Bazar (18th-16th century BCE) [47] and in a tomb complex in Tell Mishrife (Qatna), which had remained sealed since the 14th century BCE, at the time of the Hittite conquest 
of Syria [48]. The earliest scientific result supporting the development of a shellfish dyeing industry was achieved by analyzing samples of pottery vessels from a Minoan facility (ca. 1800/1700 BCE) in Alatsomouri-Pefka, in the island of Crete in the Aegean Sea [49]. These Cretan findings are earlier than the discovered Phoenician pottery sherds, suggesting that the Murex purple of the Minoans became the Tyrian purple of the Phoenicians and later the imperial purple of Byzantium [50]. Consequently, the findings in Chagar Bazar and Alatsomouri-Pefka are the earliest textile fragments and dyeing facilities associated with shellfish purple.

The discussion now focuses on the shell deposits found in the Mediterranean. In the eastern shores of the basin, significant deposits of shells have been discovered in various sites in the Aegean islands, which are dated to the 18th century BCE [51,52]. The earliest archaeological evidence comes from Crete and corresponds to the Old Palace Period and particularly in 19th-18th century BCE [53-55]. There is no evidence suggesting that the famous heaps of mollusk fragments found in Tyre are associated with a dyeing industry, which is dated earlier than the 17th century BCE [56]. Consequently, the available scientific and archaeological evidence suggest that the Minoans in the Aegean and probably the Hurrians in Syria have pioneered the extraction of shellfish purple centuries before the Tyrians.

On the other hand, there is no doubt that the purple dye industry of the Phoenicians became famous and dominated the market from the Homeric times (9th-7th century BCE) onwards [54]. The Phoenicians spread their trade and founded cities, ports and bases up to the Black Sea and across the Mediterranean basin and beyond the Pillars of Hercules. For example, the Phoenicians founded Gadir (Cádiz, Spain) and probably had visited the Canary Islands. In fact, the word "Phoenician" comes from the Greek word "Phoenix" ( the purple pigment/dye with the Phoenicians. However, based on the available archaeological and scientific data, the shellfish purple industry was developed by the Minoans and probably the Hurrians before the Phoenicians.

Finally, it should be stressed that thousands of M. trunculus shells were found in Coppa Nevigata, Italy [56-59]. The accumulations of shells are present in the Early Proto-Apennine layers [58,59]. In particular, the collection of Murex began in the 19th-18th century BCE and continued throughout the entire Bronze Age, reaching its highest peak in the 15th and 14th centuries BCE [59]. The large quantity and the condition of the shells in Coppa Nevigata suggest that they were likely to have been used for the extraction of purple [57-59]. This may be the earliest known for the industry of purple, predating that from the Aegean islands [56,58]. It is interesting to note that excavation data indicate the existence of trading activities between Coppa Nevigata and the islands of the Aegean Sea [57].

\section{Identification of Shellfish Purple in Archaeological Objects}

\subsection{Paints, Pigments and Identification Methods}

The goal of this section is twofold: (i) To summarize the scientific identifications of shellfish purple pigments applied as paints on wall paintings and some other objects and (ii) to briefly discuss the analytical techniques used for identification purposes. Both, previously reported identifications and analytical techniques are summarized in Table 1 [37-43,46,60-74]. The latter shows that shellfish purple was used in different objects for painting purposes, uninterrupted by all major pre-Roman civilizations of the Aegean, starting with the Minoan period of the Late Bronze Age up to the Hellenistic period. The use of shellfish purple was disrupted abruptly with the conquest of Constantinople by the Ottomans (1453 CE). At that time the capital of the Byzantine Empire was the major processing center of the valuable material. Around the same time in the West, a decree (1464 CE) of Pope Paul II, stipulated the replacement of shellfish purple by kermes to dye ecclesiastical robes. The two events combined, brought the historical use of shellfish purple to an end. According to Table 1, the most recent historical object painted with true purple is a wall painting in France dated to the 12th century CE [74]. It was suggested that probably the purple pigment was transported there from the eastern coast of the Mediterranean Sea during the time of the Crusades [74]. 
Table 1. Identifications of shellfish purple in pigments/paints corresponding to various historical periods and geographical locations. The techniques used for identification purposes are included.

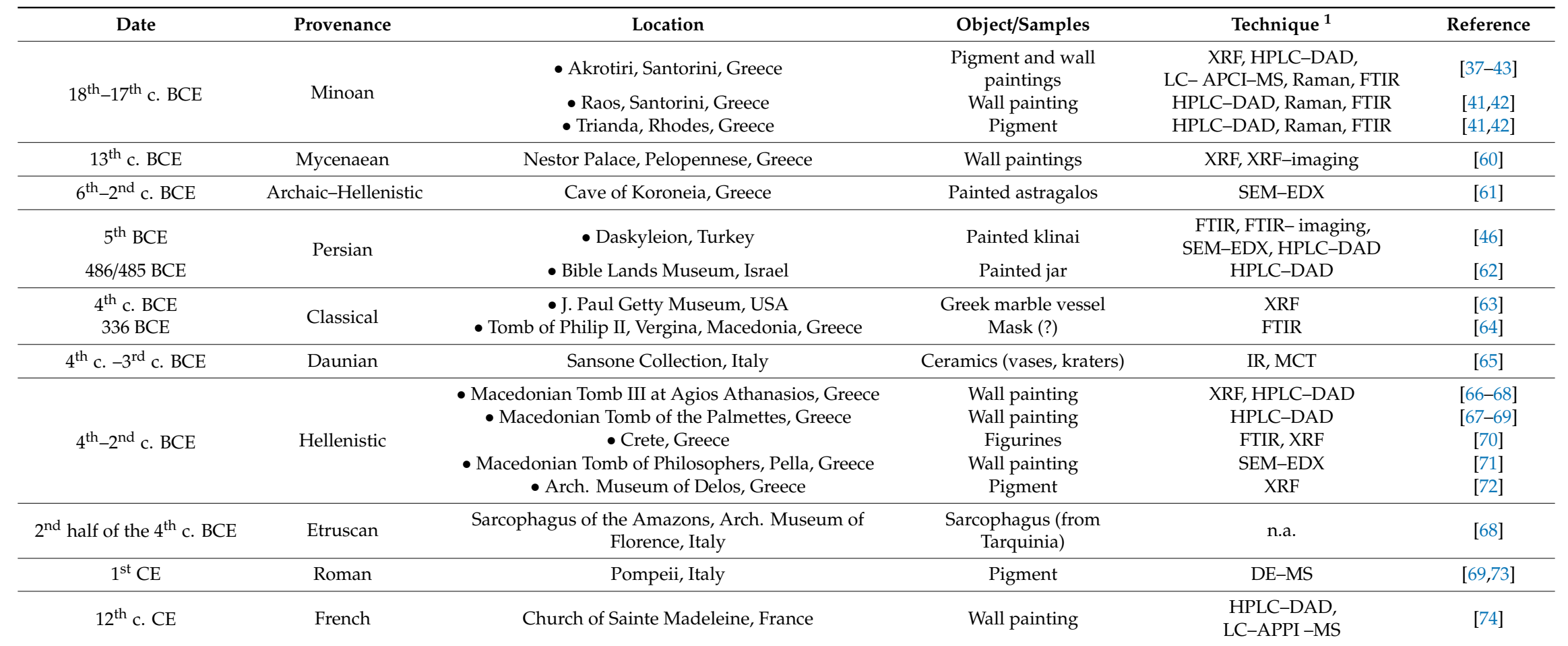

${ }^{1}$ DE-MS: direct exposure-mass spectrometry; FTIR: Fourier transform infrared spectroscopy; HPLC-DAD: high performance liquid chromatography-diode array detector; IR: infrared spectroscopy; LC-APCI-MS: liquid chromatography with atmospheric pressure chemical ionization-mass spectrometry; LC-APPI-MS: liquid chromatography with atmospheric pressure photoionization-mass spectrometry; MCT: Microchemical testing; Raman: Raman spectroscopy; SEM-EDX: scanning electron microscopy (SEM) coupled to energy dispersive x-ray (EDX) spectroscopy; XRF: X-ray fluorescence; n.a.: not available. 
As described in Table 1 a large variety of techniques were used to identify paints and pigments of shellfish purple. The presence of bromine ( $\mathrm{Br}$ ) in the composition of the purple material (Figure 3c) offers the option to apply elemental analysis techniques, such as $\mathrm{X}$-ray fluorescence $(\mathrm{XRF})$ and scanning electron microscopy (SEM) coupled to energy dispersive $x$-ray (EDX) spectroscopy (SEM-EDX). The results should be carefully interpreted considering that lichens can contain significant amounts of Br. An example of a SEM-EDX study is provided in Figure 4, which shows the results for a purple painted sample extracted from a burial klinai [46]. The detection of $\mathrm{Br}$ is indicative for the use of true purple. Furthermore, the presence of an aluminosilicate compound and gypsum is supported by the results of Figure 4, as $\mathrm{Al}, \mathrm{Si}, \mathrm{Ca}$ and $\mathrm{S}$ are included in the detected elements of the EDX spectrum. FTIR measurements confirmed the presence of shellfish purple, kaolinite and gypsum in the archaeological sample [46]. Interestingly, the use of kaolinite in painting techniques of shellfish purple were previously reported in the analyses of the Darius I stone painted jar [62] and the pigment powder of Pompeii [73]. According to Table 1, vibrational spectroscopy, and particularly FTIR and Raman spectroscopy, is another set of techniques which was effective to identify purple pigments and paints in objects of the cultural heritage.

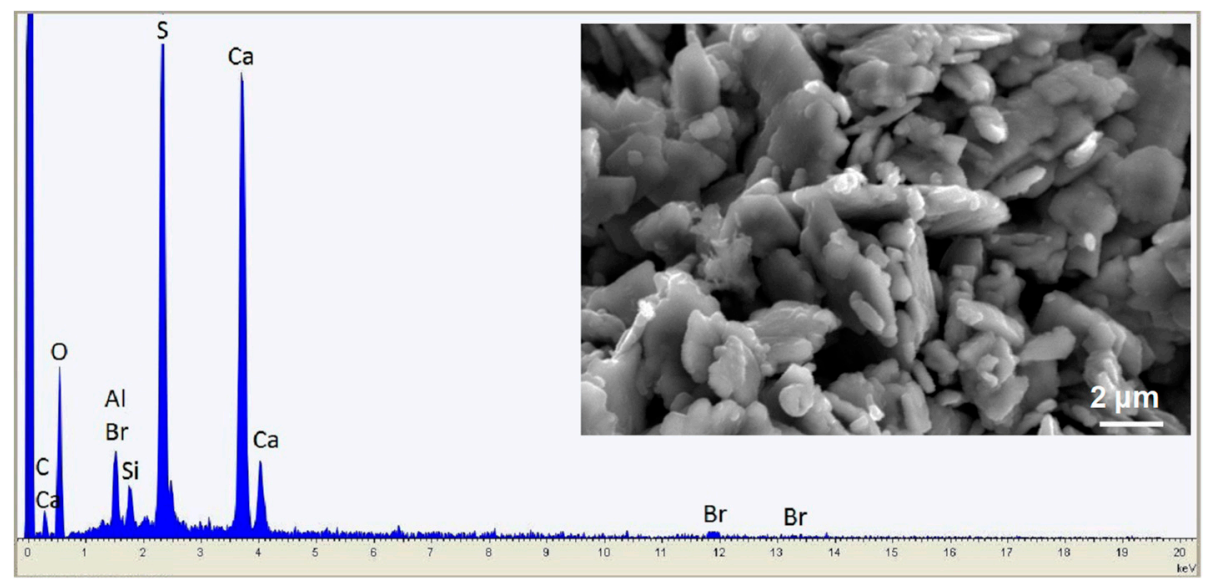

Figure 4. SEM-EDX analysis of a purple painted sample, which was extracted from a burial klinai, in Daskyleion, Turkey. Reprinted with permission form reference number [46].

High performance liquid chromatography-diode array detector (HPLC-DAD) is the most efficient among the techniques listed in Table 1 for the analysis of shellfish purple, as it provides: (i) Detection and identification of all seven components within a single measurement-chromatogram, (ii) semi-quantitative results relative to the composition of the detected purple pigment and (iii) complete quantitative results. Examples for these valuable sets of HPLC results are provided next.

The chromatogram for a purple pigment that was found in the Akrotiri settlement is shown in Figure 5. The sample was included in a previous study and labeled Ak3 [42]. The chromatogram is presented herein for the first time. INR was not detected in the sample extract. The other six components of shellfish purple are identified by HPLC, which therefore provides very rich results in terms of detected compounds. 


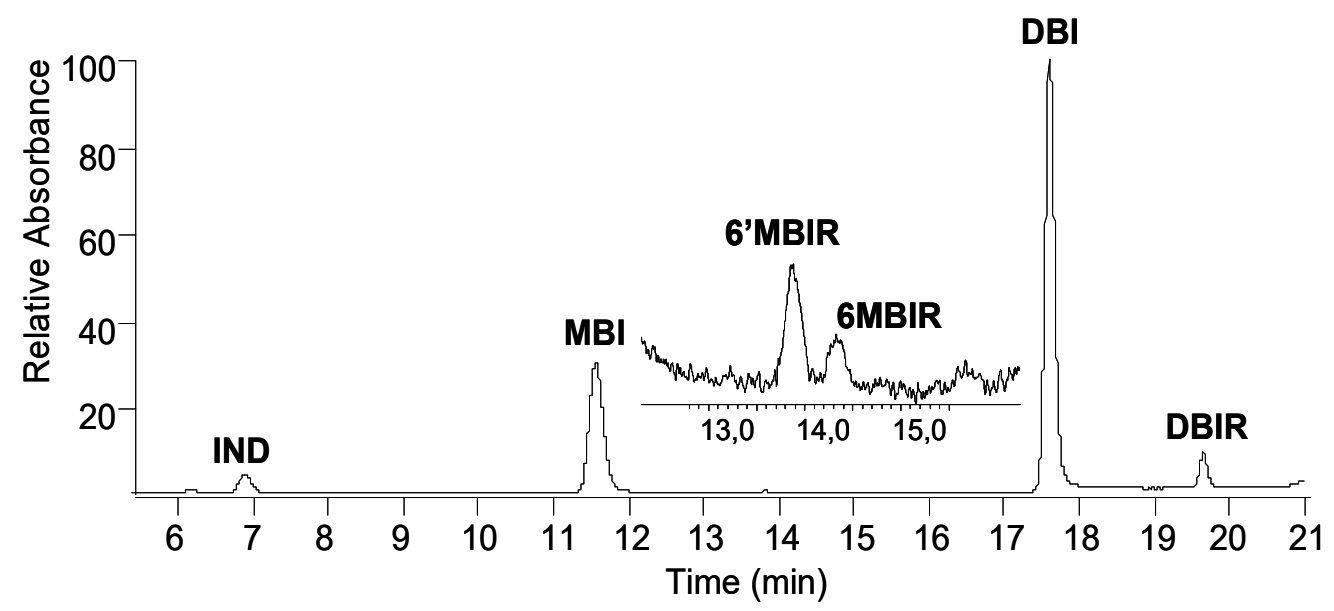

Figure 5. Chromatogram of a purple pigment from Akrotiri at $288 \mathrm{~nm}$ (Ak3 in [42]).

The HPLC peak areas (semi-quantitative results) are extremely useful to compare shellfish purple pigments from different samples. HPLC peak areas of purple components were reported in the literature for the samples of Minoan [42] and Persian origin [46,62] of Table 1 and these are summarized in Figure 6. In particular, relative integrated HPLC peak areas measured at $288 \mathrm{~nm}$ and normalized to the highest value (taken as 100\%) are shown in Figure 6 for seven archaeological samples: Ak1 (pigment), Ak2 (wall painting), Ak3 (pigment) come from Akrotiri-Santorini, Ra (wall painting) from Raos-Santorini and Tri (pigment) from Trianda-Rhodes [42]. Samples Dar and Dask were extracted from the Darius I jar [62] and the burial klinai in Daskyleion [46], respectively. The HPLC peak areas for INR, $6^{\prime} \mathrm{MBIR}$ and $6 \mathrm{MBIR}$ were extremely small and therefore the sums of these areas are included in each sample column of the graphs of Figure 6.

The results of Figure 6a show that DBI is the dominant compound in the chromatograms of the five Minoan (Ak1, Ak2, Ak3, Tri and Ra) samples. The HPLC graphs gave moderate areas for MBI and small areas for IND and DBIR. The sum, INR + 6'MBIR + 6MBIR, is negligible or even zero (Ak2 and $\mathrm{Ra}$ ) as revealed in Figure 6b. A similar HPLC profile was collected for the Dar sample [62], which, as shown in Figure 6, does not have any major difference compared to the Minoan samples. Trade routes between the southern Aegean islands, such as Santorini and Rhodes, and the Phoenician coast were developed since the prehistoric times and this may be depicted in the similar results of the Dar and the Minoan samples. However, the Dask sample is different: The HPLC peak area of DBI is small whereas the areas of IND, MBI, DBIR and the sum of INR + $6^{\prime} \mathrm{MBIR}+6 \mathrm{MBIR}$ are large compared to the Minoan and the Dar samples. Consequently, a different processing method and/or molluskan sources should had been developed/used in Daskyleion, which is located close to the Marmara Sea, in the mainland of Turkey.

The relative peak areas reported in Figure 6 are not actual mass compositions of the samples. As mentioned previously, HPLC can provide complete quantitative results provided, however, that a HPLC calibration method is developed. The coloring components of interest should be available in pure form to be used as standards for quantitation purposes. A calibration procedure for shellfish purple pigment was previously developed and showed that the relative percentage of IND reported commonly using the HPLC peak areas at $288 \mathrm{~nm}$ (e.g., Figure 6) is in fact an overestimation of the actual mass content of IND [75]. On the other hand, the corresponding relative percentage of DBI, which is calculated using the HPLC peak areas at $288 \mathrm{~nm}$, is an underestimation of the actual mass content of DBI in the shellfish pigment [75]. Moreover, the calibration process showed that low limits-of-detection (LODs) can be achieved with HPLC for the seven components of shellfish purple, ranging within 0.02 to $0.05 \mu \mathrm{g} \mathrm{mL} \mathrm{m}^{-1}$ [75].

Finally, as described in Table 1, other methods employed to analyze and identify shellfish purple pigments/paints in objects of the cultural heritage are mass spectrometry (LC-MS, direct exposure-mass 
spectrometry-DE-MS) as well as imaging techniques including FTIR and XRF imaging. The latter are useful to reveal the distribution of shellfish purple on a painted surface, which, in turn, is sometimes useful to understand the applied painting technique.

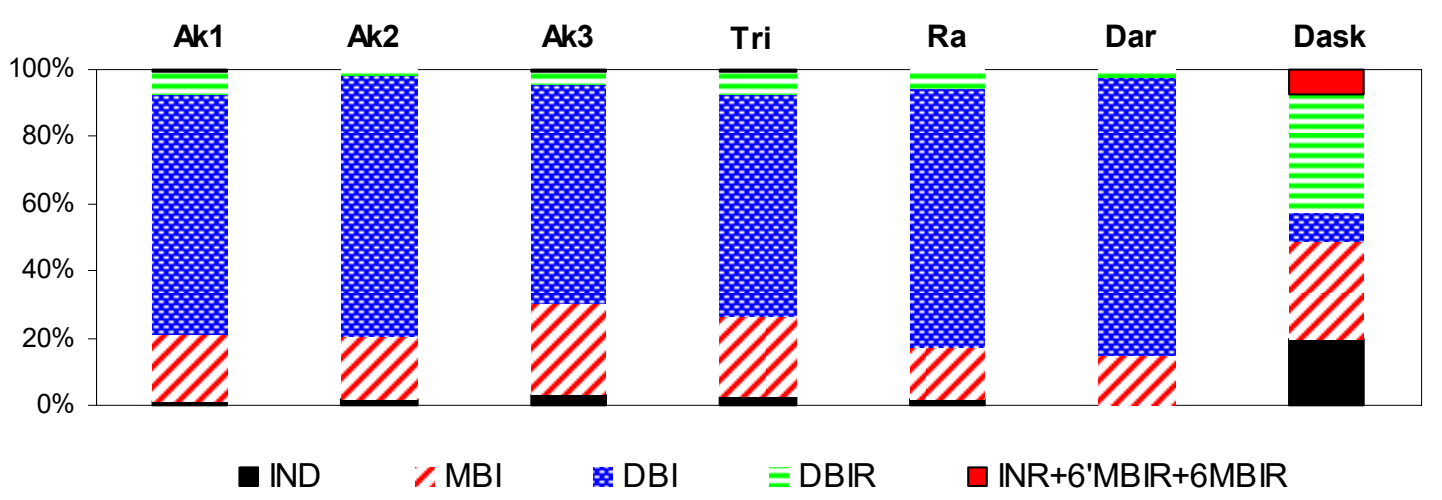

(a)

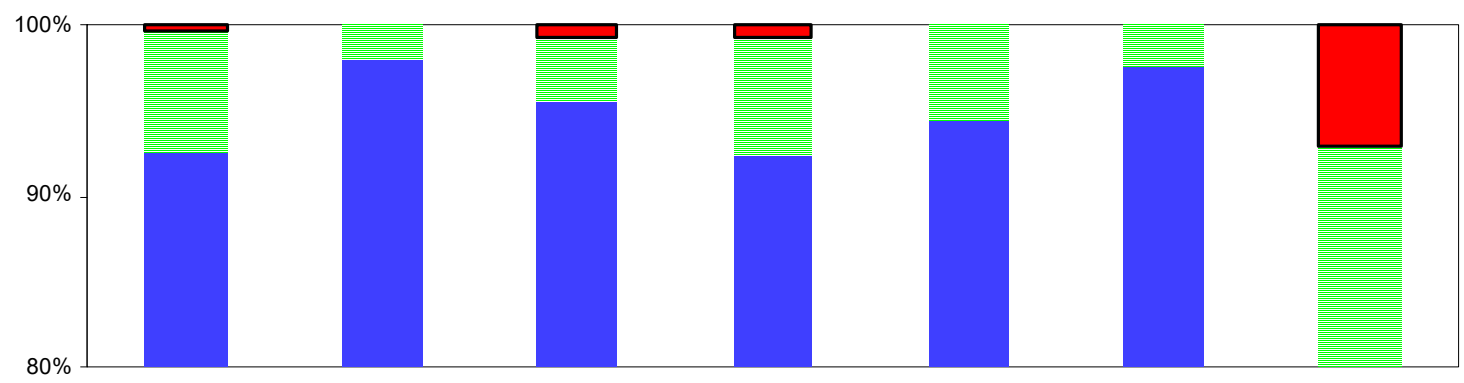

(b)

Figure 6. (a) Relative integrated HPLC peak areas measured at $288 \mathrm{~nm}$ and normalized to the highest value (taken as $100 \%$ ) are shown for seven archaeological samples. The 18th-17th century BCE samples come from the Minoan sites in Akrotiri-Santorini (Ak1, Ak2, Ak3), Raos-Santorini (Ra) and Trianda-Rhodes (Tri) [42]. Samples Dar and Dask were extracted from the Darius I painted jar [62] and the burial klinai in Daskyleion [46], respectively, both dated to the 5th century BCE. The sums of the HPLC peak areas of INR, $6^{\prime}$ MBIR and 6MBIR are included in the graph. (b) The upper $(80 \%-100 \%)$ part of the (a) graph is enlarged.

\subsection{Textiles}

As mentioned previously, the earliest direct scientific evidence of the shellfish dyeing industry were reported for textile fragments unearthed in Chagar Bazar (18th-16th century BCE) [47] and Tell Mishrife [48] and pottery vessels from Crete (ca. 1800/1700 BCE) [49]. The most recent historical textile dyed with shellfish purple is a Byzantine epitaphios, which is dated to the 14th century CE [42] i.e., roughly about the time of the fall of Constantinople.

Shellfish purple has been identified in several textiles and objects related to the textile industry of antiquity e.g., post sherds [7,30-34,36,42,46-49,58,76-104]. As summarized in Table 2, it has been scientifically proved that the valuable dye was used by the Minoans, Hurrians, Phoenicians, Persians, Greeks (in various periods), Etruscans, Jews, Romans, Sarmatians, Copts-Egyptians, Arabs (pre-Islamic period) and Byzantines. These results show that the shellfish purple dye has a long established history of use that spans roughly 3.5 millennia, as it was used uninterrupted from the prehistoric up to the Byzantines times. 
Table 2. Identifications of shellfish purple in textiles corresponding to various historical periods.

\begin{tabular}{ll}
\hline \multicolumn{1}{c}{ Provenance } & \multicolumn{1}{c}{ Reference } \\
\hline Minoan (Crete) & {$[49]$} \\
Hurrian (Chagar Bazar, Qatna) & {$[47,48]$} \\
Phoenician & {$[76-81]$} \\
Phoenician-Punic & {$[82]$} \\
Submycenaean/Protogeometric (Greek) & {$[83]$} \\
Orientalising/early Archaic (Etruscan) & {$[84]$} \\
Archaic (Greek) & {$[85]$} \\
Persian & {$[46]$} \\
Classical (Greek) & {$[7,86-88]$} \\
Hellenistic (Greek \& Etruscan) & {$[58,89-91]$} \\
Jewish & {$[92]$} \\
Roman & {$[31-33,93-96]$} \\
Sarmatian & {$[97,98]$} \\
Coptic-Egyptian & {$[34,97,99-104]$} \\
Arab (pre-Islamic period) & {$[36]$} \\
Byzantine & {$[7,30,42]$} \\
\hline
\end{tabular}

Case Study: Identification of Shellfish Purple in a Hellenistic Textile

In 1987 an excavation was carried out in a burial mount in the area of Lakkoma (Macedonia, Greece), which revealed a large cist tomb dating in the last quarter of the 4th c. BCE (Hellenistic period) [89]. Lakkoma is located around $60 \mathrm{~km}$ east of Aigai (Vergina), where the Royal Tomb of Philip II, the father of Alexander the Great, was found. The aforementioned dating of the burial is supported by a golden quarter stater of Philip II [89]. Textile purple residues and other organic materials were found within the tomb and investigated in the past using microscopic techniques [89].

A small piece of the textile residues was treated with hot dimethyl sulfoxide (DMSO) to extract the purple dye, which was analyzed using an established HPLC-DAD method [42,75]. This is the first reported HPLC analysis of a purple textile found in the mainland of Macedonia. The chromatogram is presented in Figure 7. The HPLC peaks corresponding to MBI, DBI and DBIR are dominant in the graph. IND, 6'MBIR and 6MBIR correspond to very small peaks, whereas INR was not detected.

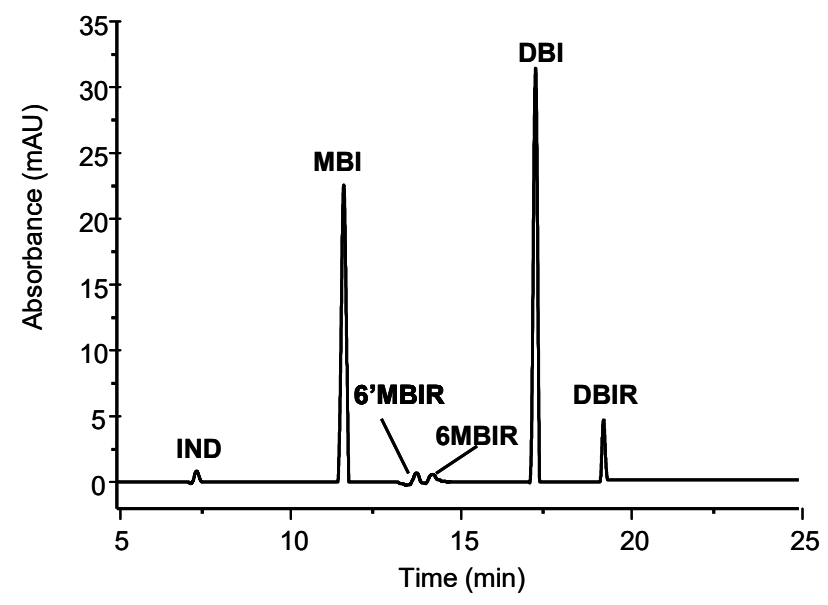

Figure 7. Chromatogram of a purple textile sample from the Lakkoma tomb at $288 \mathrm{~nm}$.

It is interesting to note that the HPLC profile in Figure 7 is not very different from that of Figure 5, which is representative of the Minoan purple paints and pigments. Consequently, based on the results of the present study it is reported that no major difference is observed in the chemical compositions of the shellfish purple materials used by the Minoans (Figure 5) and the Macedonians (Figure 7). 
Apparently this is not a general conclusion; it is an observation based on the chemical results of the tested samples.

\subsection{Manuscripts}

The scientific investigation of historical manuscripts is a challenging task. While samples can be removed from large-scale objects with relatively little impact on the integrity of the object, the removal of even tiny samples from manuscripts is practically prohibited. Consequently, the study of historical manuscripts is limited to non-sampling techniques, such as, for instance, XRF [105-108], fiber optics UV-Vis diffuse reflectance spectrophotometry with optical fibres (FORS) $[106,108]$ and Raman spectroscopy $[108,109]$. Recent advances in the development of non-sampling methods to identify shellfish purple offer new perspectives for the investigation of historical manuscripts, artworks and other objects of the cultural heritage $[110,111]$. In any case, the limitation to use only non-sampling techniques increases the degree of difficulty in studying manuscripts.

The results reported in the literature do not suggest a widespread use of shellfish purple in historical manuscripts. In particular, the use of shellfish purple has been suggested in very few objects such as, for instance, in a Byzantine (6th century CE) [105], Italian (6th century CE) [106] and Anglo-Saxon (8th century CE) [107] manuscript. The use of shellfish purple was suggested according to XRF results, which revealed the presence of $\mathrm{Br}$ [105-107]. FORS results, however, did not confirm the presence of shellfish purple. Analyses yield the information that the chromatic features of manuscripts are dominated by the presence of inorganic and organic colorants other than shellfish purple [105-112].

\subsection{Other Uses of Shellfish Purple}

In a recently published report, shellfish purple was identified by XRF and HPLC in a mass of clay material, which was stored within a compartment of a small case [113]. The lidded box was found in the grave B of Derveni (Macedonia, Greece) dated to the 4th century BCE, together with other goods, including the famous Derveni krater and a gold coin of Philip II. Based on the current archaeological data, related with other metal cases that have been unearthed in Macedonian burials, it is estimated that the content of the Derveni metal case was probably used for medical purposes [113]. If true, then this is the first scientific evidence about the medical use of shellfish purple in antiquity. It is noteworthy, that recent studies revealed that mollusks from the family Muricidae produce biological active compounds with anti-inflammatory, anti-cancer, muscle-relaxing and pain relieving properties as well as steroidogenic activity [114,115]. Some of these properties are found in the Murex extracts and have been known since antiquity [116].

The finding in Derveni is not the only one revealing the use of shellfish purple as grave good. Shellfish purple was identified by DE-MS, Raman spectroscopy and HPLC in residues collected from a Gallo-Roman burial (Naintré, France) dated to the 3rd century CE [117]. Purple was widely spread after the deposition of the body for burial, suggesting that the valuable purple grave good was part of the funeral practice [117].

Murex snails and shells have been probably used in jewels, tools and foods [118], as well as in fillers and plasters as discussed next. It was previously described that the chalk base of the Akrotiri-Santorini pigment was rich in aragonite, indicating that this was probably obtained from crushed Murex shells [43]. Shell fragments of mollusks are sometimes visible in plaster surfaces, dated from the Middle Bronze Age onwards $[118,119]$. Murex shells in the perimeter of the 5th century BCE wall of Hermione, Greece are shown in the photograph of Figure 8. Moreover, results provided from experimental archaeology demonstrated that Murex shells can be used as a raw material for lime making, but that this is not necessarily visible in its end product if done thoroughly and properly [118]. Consequently, the use of Murex shells in the lime plaster production process can be older than the reported visible archaeological evidence. Murex species might have been used to add color in plaster, as suggested by XRD analysis in painted plaster samples from Gla, Greece [120]. XRD lead to the 
identification of aragonite in the investigated plaster samples, but the presence of Murex was not confirmed by SEM-EDX [120] or Raman [121] results.

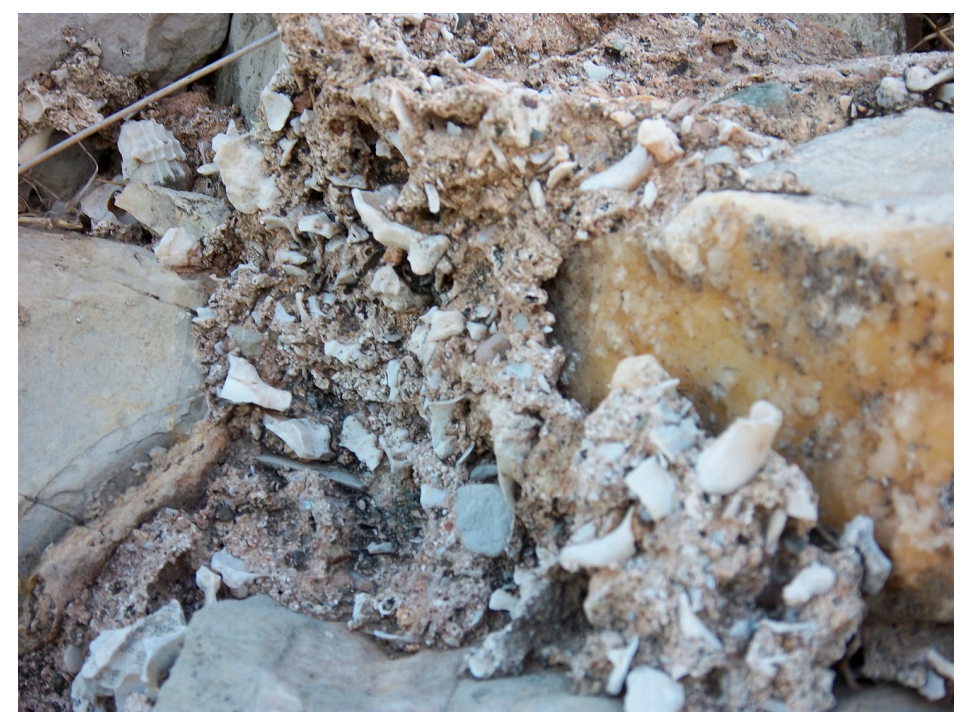

Figure 8. Murex shells used as binder in the wall of Hermione, next to the Bisti area where the famous local dyeing workshops were located (photograph by V. Gatsos).

\section{Purple but not True Purple}

Shellfish purple was held in high esteem, as it is hard to be produced in large amounts from the molluskan raw source. In his pioneering work, Friedländer collected 12,000 M. brandaris extracting only $1.4 \mathrm{~g}$ of dry pigment [24]. It is estimated that 10,000 M. trunculus mollusks are needed to dye a kilogram and a half of wool [122]. Consequently, shellfish purple had always been an expensive material, which was sparingly used. Alternative procedures to mimic true purple had been developed and therefore "not all purples were equal, and not all purple was purple" [123].

For example, mixtures of Egyptian blue with red pigments were used in painting plasters to achieve a purple hue [124]. For the same reason, blue pigments and paints of Lapis lazuli [125] and indigo/woad [121] had been used in painting backgrounds since the Mycenaean period. Egyptian blue mixed physically with a red lake, which however is unidentifiable, was revealed in wall paintings fragments in Egypt [63]. Mixture of Egyptian blue and a red-pink lake was also found in 3rd century BCE oinochoe (British Museum) [45]. According to HPLC results, the lake was derived from purpurin-rich madder, cochineal (Porphyrophora spp.) and, unexpectedly, lac (Kerria Lacca Kerr) [45]. Mixtures of purpurin-rich madder and Armenian cochineal Porphyrophora hamelii Brandt were found in funeral figurines dated to 3rd-2nd century BCE [126,127].

A common practice for the Egyptian dyers was to mix madder and indigo/woad $[8,34,93]$ achieving a remarkable purple hue. The purple mixture was sometimes enriched with a coccid dye, such as, kermes [128]. An analogous practice was revealed in Roman-Egyptian mummy portraits (2nd century $\mathrm{CE}$ ) in which mixtures of madder lakes and indigo were identified and were probably applied as cheaper substitutes for shellfish purple [129]. Kermes in mixture with indigo/woad—but not madder-was identified in purple parts of a textile from the Topkapi Palace [130].

Folium and particularly orchil were widely used as alternatives to shellfish purple in the coloring of parchments in which the use of true purple was extremely rare [112,131,132], as discussed previously. Orchella weeds, when properly processed, provide a bright purple, which has been often detected in illuminated manuscripts [108,133]. 


\section{Dyeing with Shellfish Purple: From Purple to Blue}

Dyeing with shellfish is complicated. The colored water-insoluble extract must be chemically reduced in the dye vat to give the water-soluble and colorless leuco-forms of the compounds of Figure 3c. Reduction is induced by bacteria according to the mechanism that was elucidated for the reduction of woad [134]. The dyeing process can have an enormous effect on the composition and therefore the color of the attached dye considering that several parameters have to be adjusted in the vat (treatment time, temperature, $\mathrm{pH}$, etc.). Moreover, sunlight can induce debromination of the leuco forms, which, moreover, do not have the same affinity for textile fibers [29].

The dramatic effect of the dyeing conditions on the composition of the attached dye is demonstrated in the following experiment. M. trunculus mollusks were collected by V. Gatsos from the sea of Hermione, Greece. The city of Hermione was famous for the fine dyeing with shellfish purple, an industry that had been flourished for more than 1000 years, from 6th century BCE to 6th century CE [12]. It was the Hermione purple that caused the admiration of Alexander the Great when he took Susa in 331 BCE and found purple garments in the palace of Darius III [7,12]. Wool and cotton were dyed by V. Gatsos following two recipes. Large mollusks (M. trunculus) were collected at a depth of 2-3 m, from the sea, just next to the ancient wall of Hermione.

Recipe I: The shells were crushed using a stainless steel tod at the third helix where the gland of the mollusk could be easily reached. The glands were quickly removed to preserve the secretions and placed in a flask containing $30 \mathrm{ml}$ of water and $2 \mathrm{~g}$ of common salt. The flask was left open and was rigorously agitated 3-4 times per day for 15 days. After this process the pulp became purple. For the dyeing process, the purple pulp was transferred to a glass container. Ten (10) $\mathrm{g}$ of honey and $3 \mathrm{~g}$ of salt were added. The container was airtight sealed, agitated and remained into a water bath which was heated at $45^{\circ} \mathrm{C}$ for two days. Then a $1 \mathrm{~cm} \times 3 \mathrm{~cm}$ piece of fabric (wool or cotton) was immersed into the mixture and additional amounts of honey $(2 \mathrm{~g})$ and salt $(1 \mathrm{~g})$ were added. The container was airtight sealed, agitated and remained into a water bath which was heated at $45^{\circ} \mathrm{C}$ for one day. The fabric was removed and washed with warm water $\left(70{ }^{\circ} \mathrm{C}\right)$ and soap solution.

Recipe II: The shells were crushed and the glands were placed in a flask containing $80 \mathrm{~mL}$ of water and huge amount ( $20 \mathrm{~g})$ of common salt. The flask was left in the sunlight for five days. Then, the dyeing procedure described in recipe I was followed.

Consequently, in recipe II, extreme conditions related to the quantity of salt and the duration of sunlight exposure were selected. The possible role of salt in the dyeing process is critically discussed in detail by C. Cooksey [18]. The four samples, two wools and two cottons, dyed with the two recipes, were analyzed using HPLC. A DMSO bath at $80^{\circ} \mathrm{C}$ was used to extract the purple dyes [42]. The $\%$ relative integrated HPLC peak areas were measured and the results are provided in Table 3. The two recipes gave totally different results, as a dominant debromination process was developed in recipe II, resulting in reduced amounts of brominated indigoids (MBI and DBI) attached to the fibers. IND is clearly the major coloring compound in the samples, which were prepared using recipe II. On the contrary, large amounts of MBI were attached to fibers dyed with recipe I. The difference of the two recipes in the dyeing results was visible by naked eye, as samples prepared using recipe I were purple whereas samples that were dyed using recipe II were blue. 
Table 3. Relative (\%) integrated HPLC peak areas measured at $288 \mathrm{~nm}$ for wool and silk, which were dyed with two recipes, as described in the text.

\begin{tabular}{ccccc}
\hline \multirow{2}{*}{ Compound. } & \multicolumn{2}{c}{ Recipe I } & \multicolumn{2}{c}{ Recipe II } \\
\cline { 2 - 5 } & Wool & Cotton & Wool & Cotton \\
\hline IND & 11.9 & 8.5 & 70.3 & 94.4 \\
MBI & 56.5 & 44.7 & 16.0 & 3.3 \\
DBI & 29.1 & 4.5 & 8.8 & 1.7 \\
INR & - & - & - & - \\
6'MBIR & 0.2 & 0.2 & & - \\
6MBIR & 0.2 & 0.1 & 1.2 & - \\
DBIR & 2.0 & 1.9 & 3.7 & 0.6 \\
\hline
\end{tabular}

\section{Solubility Issues}

Solubility data is available in the open literature for indigo, which contains indigotin and indirubin but not their brominated derivatives. Table 4 shows the solubility of indigo in ten solvents [135]. The results of Table 4 were calculated using the COSMO-RS (conductor-like screening model for real solvents), which is a quantum-mechanical approach [135]. The best solvent found is sulfuric acid, in which COSMO-RS predicts complete miscibility with indigo. On the other hand, water practically does not dissolve indigo.

Table 4. Results of the conductor-like screening model for real solvents (COSMO-RS) solubility screening for indigo. The results were adapted from elsewhere [135].

\begin{tabular}{cccc}
\hline \multicolumn{2}{c}{ Recipe I } & \multicolumn{2}{c}{ Recipe II } \\
\hline Sulfuric acid & 100.0000 & Pyrrole & 4.1934 \\
Dimethyl sulfoxide & 11.9093 & Chloroform & 1.6337 \\
Phenol & 10.4013 & Diethylether & 1.4813 \\
Propanone & 6.5225 & Ethanol & 0.4694 \\
Pyridine & 4.3329 & Water & 0.0001 \\
\hline
\end{tabular}

Efficient extraction of dyes from fiber samples is important for successful HPLC analysis of textiles of the cultural heritage. Among the solvents included in Table 4, DMSO [42,62] and pyridine $[42,97]$ were suggested for the extraction of shellfish purple from archaeological samples. Moreover, N,N-dimethylformamide (DMF), which is not included in Table 4, was also used for the extraction of the purple material [42,78]. DMSO and DMF have similar solubility properties considering that they have comparable Hansen solubility parameters [136]. The latter are summarized in Table 5 for the three aforementioned solvents.

Table 5. Hansen solubility parameters: $\delta_{\mathrm{d}}, \delta_{\mathrm{p}}$ and $\delta_{\mathrm{hb}}$ are the dispersion, polar and hydrogen bonding parameters, respectively [136].

\begin{tabular}{cccc}
\hline Solvent & $\boldsymbol{\delta}_{\mathbf{d}}$ & $\boldsymbol{\delta}_{\mathbf{p}}$ & $\boldsymbol{\delta}_{\mathbf{h b}}$ \\
\hline Dimethylsulfoxide & 18.4 & 16.4 & 10.2 \\
N,N-dimethylformamide & 17.4 & 13.7 & 11.3 \\
Pyridine & 19.0 & 8.8 & 5.9 \\
\hline
\end{tabular}

The efficiencies of DMSO, DMF and pyridine to solubilize shellfish purple were compared using HPLC [42]. The experimental results showed that DMSO and pyridine result in very good and poor yields, respectively [42], which is in agreement with the prediction for indigo provided by the COSMO-RS (Table 4). Moreover, the experimental study showed that DMSO and DMF have comparable efficacy in solubilizing shellfish purple [42], which is in agreement with the similar Hansen solubility parameters of these two solvents (Table 5). 


\section{Conclusions}

The conclusions of the review are summarized as follows:

- From the Minoan period to the cease of the Byzantine empire with the conquest of Constantinople by the Ottomans, shellfish purple had a significant role in painting art and textile industry, as suggested by chemical analyses (Tables 1 and 2; Figures 4-7) and depicted in various objects of cultural heritage (Figure 1).

- $\quad$ Not all purples were true purple, as procedures to mimic the purple hue had been developed by mixing blue and red pigments, lakes or dyes. Imitation of true purple was a common practice in purple manuscripts, as physicochemical analyses do not suggest a widespread use of the shellfish material on codices and manuscripts.

- $\quad$ Other past uses of shellfish purple in medicine, grave goods and wall construction (Figure 8) are supported by the literature.

- Dyeing conditions, such as sunlight and salt concentration, can have a dramatic effect on the composition of the purple dye and can therefore affect the color of the dyed textile, which can range from blue to purple (Figure 3; Table 3).

- The first HPLC analysis of a purple textile dated in the Hellenistic period was reported, herein. The textile fragment was found in the Macedonian tomb of Lakkoma (Northern Greece). The chromatogram was dominated by the peaks, which corresponded to 6-bromoindigotin, 6,6'-dibromoindigotin and 6,6'-dibromoindirubin (Figure 7).

- Dimethylsulfoxide and dimethylformamide are good solvents for indigoids dyes as suggested by experimental studies and theoretical predictions based on statistical mechanics (Tables 4 and 5).

- Marine species, including the mollusks of the Muricidae family are threatened by sea pollution and global warming (Figure 2). Action is needed to protect the shellfish, which for so many centuries have offered so much to us.

Funding: This research received no external funding.

Acknowledgments: The author thanks M.T.-A. and V.V. for providing the archaeological sample from the tomb at Lakkoma, A.V. for her assistance in the analysis of the sample, V.G. and S.P. for providing the dyed textiles and M.G. and S.S. for useful discussions.

Conflicts of Interest: The author declares no conflict of interest.

\section{References}

1. Liritzis, I.; Korka, E. Archaeometry's role in cultural heritage sustainability and development. Sustainability 2019, 11, 1972. [CrossRef]

2. Degano, I.; Ribechini, E.; Modugno, F.; Colombini, M.P. Analytical methods for the characterization of organic dyes in artworks and in historical textiles. Appl. Spectrosc. Rev. 2009, 44, 363-410. [CrossRef]

3. Nigra, B.T.; Faull, K.F.; Barnard, K. Analytical chemistry in archaeological research. Anal. Chem. 2015, 87, 3-18. [CrossRef] [PubMed]

4. Orna, M.V. Historic Mineral Pigments: Colorful Benchmarks of Ancient Civilizations. In Chemical Technology in Antiquity; Rasmussen, S.C., Ed.; ACS Symposium Series; American Chemical Society: Washington, DC, USA, 2015; Volume 1211, pp. 17-69.

5. Henshilwood, C.S.; D’Errico, F.; Van Niekerk, K.L.; Coquinot, Y.; Jacobs, Z.; Lauritzen, S.-E.; Menu, M.; García-Moreno, R. A 100,000-year-old ochre-processing workshop at Blombos Cave, South Africa. Science 2011, 334, 219-222. [CrossRef] [PubMed]

6. Splitstoser, J.C.; Dillehay, T.D.; Wouters, J.; Claro, A. Early pre-Hispanic use of indigo blue in Peru. Sci. Adv. 2016, 2, e1501623. [CrossRef] [PubMed]

7. Hofenk-de Graaff, J.H. The Colourful Past: Origins, Chemistry and Identification of Natural Dyestuffs; Archetype Publications Ltd: London, UK, 2004.

8. Cardon, D. Natural Dyes-Sources, Tradition Technology and Science; Archetype Publications Ltd: London, UK, 2007. 
9. Cooksey, C. Tyrian purple: The first four thousand years. Sci. Prog. 2013, 96, 171-186. [CrossRef] [PubMed]

10. Moran, W.L. The Amarna Letters; Johns Hopkins University Press: Baltimore, MD, USA, 1992; pp. 53-79.

11. Ventris, M.G.F.; Chadwick, J. Documents in Mycenaean Greece, 2nd ed.; Cambridge University Press: Cambridge, UK, 1973; p. 573.

12. Kalaitzaki, A.; Vafiadou, A.; Frony, A.; Reese, D.S.; Drivaliari, A.; Liritzis, I. Po-pu-re: Workshops, use and archaeometric analysis in pre-Roman central eastern Mediterranean. Mediterr. Archaeol. Archaeom. 2017, 17, 103-130.

13. Graves, D.E. What is the Madder with Lydia's Purple? A re-examination of the Purpurarii in Thyatira and Philippi. Near East Archaeol. Soc. Bull. 2017, 62, 3-29.

14. British Museum Coins Phoenicia, Supplementary Plate XLIV, 7

15. Available online: https://www.britishmuseum.org/research/collection_online/collection_object_details.aspx? objectId=462267\&partId=1\&searchText=murex\&page=1 (accessed on 22 May 2019).

16. Available online: https://www.britishmuseum.org/research/collection_online/collection_object_details.aspx? objectId=1298437\&partId=1\&searchText=murex\&page=1 (accessed on 22 May 2019).

17. Rilov, G. Multi-species collapses at the warm edge of a warming sea. Sci Rep. 2016, 6, 36897. [CrossRef]

18. Cooksey, C. Pliny's first century AD recipe for a purple dye-vat-decoded. In Purpureae Vestes V: Textiles, Basketry and Dyes in the Ancient Mediterranean World; Ortiz, J., Alfaro, C., Turell, L., Martínez, J., Eds.; Universitat de València: València, Spain, 2016; pp. 217-220.

19. Wouters, J.; Verhecken, A. High-performance liquid chromatography of blue and purple indigoid natural dyes. J. Soc. Dyers Colour. 1991, 107, 266-269. [CrossRef]

20. Karapanagiotis, I.; de Villemereuil, D.; Magiatis, P.; Polychronopoulos, P.; Vougogiannopoulou, K.; Skaltsounis, A.-L. Identification of the coloring constituents of four natural indigoid dyes. J. Liq. Chromatogr. Relat. Technol. 2006, 29, 1491-1502. [CrossRef]

21. Koren, Z.C. HPLC-PDA analysis of brominated indirubinoid, indigoid, and isatinoid dyes. In Indirubin, the Red Shade of Indigo; Meijer, L., Guyard, N., Skaltsounis, A.-L., Eisenbrand, G., Eds.; Life in Progress Editions: Roscoff, France, 2006; pp. 45-53.

22. Mantzouris, D.; Karapanagiotis, I. Identification of indirubin and monobromoindirubins in Murex Brandaris. Dyes Pigment. 2014, 104, 194-196. [CrossRef]

23. Surowiec, I.; Nowik, W.; Moritz, T. Mass spectrometric identification of new minor indigoids in shellfish purple dye from Hexaplex trunculus. Dyes Pigment. 2012, 94, 363-369. [CrossRef]

24. Friedländer, P. Über den Farbstoff des antiken Purpurs aus Murex brandaris. Ber. Dtsch. Chem. Ges. 1909, 42, 765-770. [CrossRef]

25. Clark, R.J.H.; Cooksey, C.J. Monobromoindigos: A new general synthesis, the characterization of all four isomers and an investigation into the purple colour of 6,6'-dibromoindigo. New J. Chem. 1999, 23, 323-328. [CrossRef]

26. Imming, P.; Imhof, I.; Zentgraf, M. An improved synthetic procedure for 6,6'-dibromoindigo (Tyrian purple). Synth. Commun. 2001, 31, 3721-3727. [CrossRef]

27. Wolk, J.L.; Frimer, A.A. Preparation of Tyrian Purple (6,6'-dibromoindigo): Past and present. Molecules 2010, 15, 5473-5508. [CrossRef] [PubMed]

28. Ramig, K.; Lavinda, O.; Szalda, D.J.; Mironova, I.; Karimi, S.; Pozzi, F.; Shah, N.; Samson, J.; Ajiki, H.; Massa, L.; et al. The nature of thermochromic effects in dyeings with indigo, 6-bromoindigo, and 6,6 $6^{\prime}$-dibromoindigo, components of Tyrian Purple. Dyes Pigment. 2015, 117, 37-48. [CrossRef]

29. Ramig, K.; Islamova, A.; Scalise, J.; Karimi, S.; Lavinda, O.; Cooksey, C.; Vasileiadou, A.; Karapanagiotis, I. The effect of light and dye composition on the color of dyeings with indigo, 6-bromoindigo, and 6,6 dibromoindigo, components of Tyrian Purple. Struct. Chem. 2017, 28, 1553-1561. [CrossRef]

30. Koren, Z.C.; Verhecken-Lammens, C. Microscopic and chromatographic analyses of molluskan purple yarns in a late Roman period textile. e-PS 2013, 10, 27-34.

31. Cardon, D.; Nowik, W.; Granger-Taylor, H.; Marcinowska, R.; Kusyk, K.; Trojanowicz, M. Who could wear true purple in Roman Egypt? Technical and social considerations on some new identifications of purple from marine molluscs in archaeological textiles. In Textiles y Tintes en la Ciudad antigua; Alfaro, C., Brun, J.-P., Borgard, P., Pierobon Benoît, R., Eds.; Universitat de València: València, Spain, 2011; pp. 197-214.

32. Sukenik, N.; Iluz, D.; Shamir, O.; Varvak, A.; Amar, Z. Purple-dyed textiles from Wadi Murabba'at. Archaeol. Text. Newslett. 2013, 55, 46-54. 
33. Sukenik, N.; Varvak, A.; Amar, Z.; Iluz, D. Chemical analysis of Murex-dyed textiles from wadi Murabba'at, Israel. J. Archaeol. Sci. Rep. 2015, 3, 565-570. [CrossRef]

34. Karapanagiotis, I.; Verhecken-Lammens, C.; Kamaterou, P. Identification of dyes in egyptian textiles of the first millennium AD from the collection Fill-Trevisiol. Archaeol. Anthropol Sci. 2019, 11, 2699-2710. [CrossRef]

35. Moatsos, P.-G. Porphyra; Kasimati \& Iona: Alexandria, Egyt, 1932. (In Greek)

36. Ribechini, E.; Pérez-Arantegui, J.; Pavan, A.; Degano, I.; Zanaboni, M.; Colombini, M.P. First evidence of purple pigment production and dyeing in southern Arabia (Sumhuram, Sultanate of Oman) revealed by massspectrometric and chromatographic techniques. J. Cult. Herit. 2016, 19, 486-491. [CrossRef]

37. Aloupi, E.; Karydas, A.G.; Paradellis, T. Pigment analysis of wall paintings and ceramics from Greece and Cyprus. X-ray Spectrom. 2000, 29, 18-24. [CrossRef]

38. Sotiropoulou, S.; Karapanagiotis, I. Conchylian purple investigation in prehistoric wall paintings of the Aegean area. In Indirubin, the Red Shade of Indigo; Meijer, L., Guyard, N., Skaltsounis, A.-L., Eisenbrand, G., Eds.; Life in Progress Editions: Roscoff, France, 2006; pp. 71-78.

39. Karapanagiotis, I. Identification of indigoid natural dyestuffs used in art objects by HPLC coupled to APCI-MS. Am. Lab. 2006, 38, 36-40.

40. Van Elslande, E.; Lecomte, S.; Le Ho, A.S. Micro-Raman spectroscopy (MRS) and surface-enhanced Raman scattering (SERS) on organic colourants in archaeological pigments. J. Raman Spectrosc. 2008, 39, 1001-1006. [CrossRef]

41. Karapanagiotis, I.; Sotiropoulou, S.; Valianou, L. Identification of Tyrian purple in Aegean Bronze age pigments. In Proceedings of the 30th Dyes in History and Archaeology meeting, Derby, UK, 12-15 October 2011.

42. Karapanagiotis, I.; Mantzouris, D.; Cooksey, C.; Mubarak, M.S.; Tsiamyrtzis, P. An improved HPLC method coupled to PCA for the identification of Tyrian Purple in archaeological and historical samples. Microchem. J. 2013, 110, 70-80. [CrossRef]

43. Karapanagiotis, I.; Sotiropoulou, S.; Chryssikopoulou, E.; Magiatis, P.; Andrikopoulos, K.S.; Chryssoulakis, Y. Investigation of Tyrian purple occurring in prehistoric wall paintings of Thera. In The Diversity of Dyes in History \& Archaeology; Kirby, J., Ed.; Archetype Publications: London, UK, 2017; pp. 82-89.

44. Pliny. Naturalis Historia, XXXV.xxvi.44

45. Dyer, J.; Tamburini, D.; Sotiropoulou, S. The identification of lac as a pigment in ancient Greek polychromy-The case of a Hellenistic oinochoe from Canosa di Puglia. Dyes Pigment. 2018, 149, 122-132. [CrossRef]

46. Papliaka, Z.E.; Konstanta, A.; Karapanagiotis, I.; Karadag, R.; Akyol, A.A.; Mantzouris, D.; Tsiamyrtzis, P. FTIR imaging and HPLC reveal ancient painting and dyeing techniques of molluskan purple. Archaeol. Anthropol. Sci. 2017, 9, 197-208. [CrossRef]

47. Breniquet, C.; Desrosiers, S.; Nowik, W.; Rast-Eicher, A. Les textiles découverts dans les tombes de l'age du Bronze moyen a Chagar Bazar (Syrie). In Chagar Bazar (Syrie) VIII. Les Tombes Ordinaires d' L'āge du Bronze Ancien et Moyen des Chantiers D-F-H-I (1999-2011); Tunca, O., Baghdo, A., Eds.; Peeters Publishers: Lueven-Liège, Belgium, 2018; pp. 11-32.

48. James, M.A.; Reifarth, N.; Mukherjee, A.J.; Crump, M.P.; Gates, P.J.; Sandor, P.; Robertson, F.; Pfälzner, P.; Evershed, R.P. High prestige royal purple dyed textiles from the Bronze Age royal tomb at Qatna, Syria. Antiquity 2009, 83, 1109-1118. [CrossRef]

49. Koh, A.A.; Betancourt, P.P.; Pareja, M.N.; Brogan, T.M.; Apostolakou, V. Organic residue analysis of pottery from the dye workshop at Alatsomouri-Pefka, Crete. J. Archaeol. Sci. Rep. 2016, 7, 536-538. [CrossRef]

50. Edmonds, J. The trail of the purple snail. J. Weavers Spinners Dyers 2005, 214, 5.

51. Stieglitz, R.R. The Minoan origin of Tyrian purple. Biblic. Archaeol. 1994, 57, 46-54. [CrossRef]

52. Reese, D.S. Shells from Sarepta (Lebanon) and east Mediterranean purple-dye production. Mediterr. Archaeol. Archaeom. 2010, 10, 113-141.

53. Reese, D.S. Palaikastro shells and Bronze Age purple dye production in the Mediterranean basin. Annu. Br. Sch. Athens 1987, 82, 202-206. [CrossRef]

54. Veropoulidou, R. The Tyrian Purple, a "royal" dye. In Greeks and Phoenicians at the Mediterranean Crossroads; Adam-Veleni, P., Stefani, E., Eds.; Hellenic Ministry of Culture and Tourism, Archaeological Museum of Thessaloniki: Thessaloniki, Greece, 2012; pp. 103-105. 
55. Reese, D.S. The invertebrates. In Palaikastro, Building 1. Supplementary Volume I.; Macgillivray, J.A., Sackett, L.H., Eds.; The British School of Athens: Athens, Greece, 2019; pp. 387-409.

56. Reese, D.S. Shell Purple-dye Production in the Mediterranean Basin and Environs. In press.

57. Minniti, C. Shells at the Bronze Age settlement of Coppa Nevigata (Apulia, Italy). In Archaeomalacology. Molluscs in Former Environments of Human Behaviour; Mayer, D.E.B.-Y., Ed.; Oxbow Books and the individual authors: Oxford, UK, 2005; pp. 71-81.

58. Gleba, M.; Vanden Berghe, I. Textiles from Strozzacapponi (Perugia/Corciano). New evidence of purple production in pre-Roman Italy. In Purpureae Vestes IV: Production and Trade of Textiles and Dyes in the Roman Empire and Neighbouring Regions; Alfaro, C., Tellenbach, M., Ortiz, J., Eds.; Universitat de València: València, Spain, 2014; pp. 167-173.

59. Minniti, C.; Recchia, G. New evidence on purple dye production from the Bronze Age settlement of Coppa Nevigata (Apulia, Italy). In Purpureae Vestes VI: Textiles and Dyes in the Mediterranean Economy and Society; Busana, M.S., Gleba, M., Meo, F., Tricomi, A.R., Eds.; Libros Pórtico: Zaragoza, España, 2018; pp. 87-97.

60. Kokiasmanou, E. Portable XRF Analysis and MA-XRF Imaging of Mycenaean Wall-Painting Pigments from the Palace of Nestor at Pylos. Master's Thesis, Aristotle University of Thessaloniki, Thessaloniki, Greece, 2018.

61. Colombini, M.P.; Carmignani, A.; Modugno, F.; Frezzato, F.; Olchini, A.; Brecoulaki, H.; Vassilopoulou, V.; Karkanas, P. Integrated analytical techniques for the study of ancient Greek polychromy. Talanta 2004, 63, 839-848. [CrossRef]

62. Koren, Z.C. Archaeo-chemical analysis of Royal Purple on a Darius I stone jar. Microchim. Acta 2008, 162, 381-392. [CrossRef]

63. Kakoulli, I. Late Classical and Hellenistic painting techniques and materials: A review of the technical literature. Rev. Conserv. 2002, 3, 56-67. [CrossRef]

64. Maniatis, Y.; Arvaniti, T.; Antikas, T.G.; Wynn-Antikas, L.; Orsini, S.; Ribechini, E.; Colombini, M.P. Investigation of an unusual composite material found in the larnax with cremated bones in royal tomb II at Vergina. In Proceedings of the 40th International Symposium on Archaeometry, Los Angeles, CA, USA, 19-23 May 2014.

65. Sanpaolo, E.A.; Follo, L.; Sfrecola, S. Alcuni aspetti tecnologici della ceramica policroma della Daunia nella collezione Sansone di Mattinata (FG). L'apporto dell'archeometria. In Atti dell' 11 Convegno Nazionale sulla Preistoria-Protostoria, Storia della Daunia; Gravina, A., Ed.; Gerni Editori: San Severo, Italy, 1990; pp. 139-170.

66. Karydas, A.G. In situ XRF analyses of wall-painting pigments on ancient funeral Macedonian monument. In La Peinture Funeraire de Macedoine. Emplois et Fonctions de la Couleur IVe-IIe s. av. J. -C, Vol II: Planches $\mathcal{E}$ Tableaux, Appendix IV; Brecoulaki, H., Ed.; National Hellenic Research Foundation: Athens, Greece, 2006.

67. Andreotti, A.; Carmignani, A.; Colombini, M.P.; Modugno, F. Characterization of paint organic materials in wall decorations of Macedonian tombs. In La Peinture Funeraire de Macedoine. Emplois et Fonctions de la Couleur IVe-IIe s. av. J. -C, Vol II: Planches E Tableaux, Appendix IV; Brecoulaki, H., Ed.; National Hellenic Research Foundation: Athens, Greece, 2006.

68. Brecoulaki. Precious colours in ancient Greek polychromy and painting: Material aspects and symbolic values. Rev. Archéol. 2014, 1, 3-35.

69. Andreotti, A.; Colombini, M.P.; Ribechini, E.; D'Alessio, A.; Frezzato, F. The characterisation of red-violet organic colours in ancient samples. In The Diversity of Dyes in History \& Archaeology; Kirby, J., Ed.; Archetype Publications: London, UK, 2017; pp. 97-106.

70. Maravelaki-Kalaitzaki, P.; Kallithrakas-Kontos, N. Pigment and terracotta analyses of Hellenistic figurines in Crete. Anal. Chim. Acta 2003, 497, 209-225. [CrossRef]

71. Maniatis, G.; Sakelari, H.; Kavousanaki, D.; Minos, N. Physicochemical characterisation of pigments from the cist tomb of Pella. In Cist Tomb with Painting Decoration from Pella; Lilibaki-Akamati, M., Ed.; Ministry of Culture, 17th Ephorate of Prehistoric and Classical Antiquities: Athens, Greece, 2007; pp. 138-175. (In Greek)

72. Karydas, A.G.; Brecoulaki, H.; Bourgeois, B.; Jockey, P.H. In situ X-ray fluorescence analysis of raw pigments and traces of polychromy on Hellenistic sculpture and the Archaeological Museum of Delos. In Proceedings of the 7th International Conference of Association for the Study of Marble and Other Stones in Antiquity, Thassos, Greece, 15-20 September 2003; Maniatis, Y., Ed.; Suppl. 51. École française d'Athènes, BCH: Athens, Greece, 2009; pp. 811-829. 
73. Clarke, M.; Fredrick, P.; Colombini, M.P.; Andreotti, A.; Wouters, J.; Van Bommel, M.; Eastaugh, N.; Walsh, V.; Chaplin, T.; Siddall, R. Pompei purpurissum pigment problems. In Proceedings Art 2005: 8th International Conference on Non-Destructive Testing and Microanalysis for the Diagnostics and Conservation of the Cultural and Environmental Heritage; Parisi, C., Buzzanca, G., Paradisi, A., Eds.; Italian Society of Non-Destructive testing Monitoring Diagnostics AIPnD: Lecce, Italy, 2005.

74. March, R.E.; Papanastasiou, M.; McMahon, A.W.; Allen, N.S. An investigation of paint from a mural in the church of Sainte Madeleine, Manas, France. J. Mass Spectrom. 2011, 46, 816-820. [CrossRef] [PubMed]

75. Vasileiadou, A.; Karapanagiotis, I.; Zotou, A. Determination of Tyrian purple by high performance liquid chromatography with diode array detection. J. Chromatogr. A 2016, 1448, 67-72. [CrossRef] [PubMed]

76. McGovern, P.E.; Michel, R.H. Boyal purple and the pre-Phoenician dye industry of Lebanon. MASCA 1984, 3, 67-70.

77. McGovern, P.E.; Michel, R.H. Royal purple dye: Tracing chemical origins of the industry. Anal. Chem. 1985, 57, 1514A-1522A.

78. Koren, Z.C. High-performance liquid chromatographic analysis of an ancient Tyrian purple dyeing vat from Israel. Isr. J. Chem. 1995, 35, 117-124. [CrossRef]

79. Karmon, N.; Spanier, E. Archaeological evidence of the purple dye industry from Israel. In The Royal Purple and the Biblical Blue: Argaman and Tekhelet the Study of Chief Rabbi Dr Isaac Herzog on the Dye Industries in Ancient Israel and Recent Scientific Contributions; Spanier, E., Ed.; Keter Publ House: Jerusalem, Israel, 1987; pp. 147-158.

80. Karmon, N.; Spanier, E. Remains of a purple dye industry at Tel Shiqmona. Isr. Explor. J. 1988, 38, $184-186$.

81. Sukenik, N.; Iluz, D.; Amar, Z.; Varvak, A.; Bar, S. New evidence of the purple-dye industry at Tel Shiqmona, Israel. Archaeometry 2017, 59, 775-785. [CrossRef]

82. Domínguez-Bella, S.; March, R.J.; Gener, J.M.; Martínez, J. Analisis de restos organicos de la tumba punica de la Casa del Obispo, Cadiz. Reconstruyendo la memoria fenicia en el occidente del Mediterraneo. In Gadir y el Círculo del Estrecho Revisados; Domínguez-Pérez, J.C., Ed.; Servicio de Publicaciones de la Universidad de Cadiz: Cadiz, Spain, 2011; pp. 307-319.

83. Kolonas, L.; Sarri, K.; Margariti, C.; Vanden Berghe, I.; Skals, I.; Nosch, M.-L. Heirs from the loom? Funerary textiles from Stamna (Aitolia, Greece). A preliminary analysis. In Hesperos. The Aegean Seen from the West, Proceedings of the 16th International Aegean Conference, Ioannina, Greece, 18-21 May 2016; Fotiadis, M., Laffineur, R., Lolos, Y., Vlachopoulos, A., Eds.; Peeters Publishers: Lueven-Liège, Belgium, 2017; pp. 533-542.

84. Gleba, M.; Mandolesi, A.; Lucidi, M.R. New textile finds from Tomba Dell' Aryballos Sospeso, Tarquinia: Context, analysis and preliminary interpretation. Origini 2017, 40, 29-44.

85. Metallinou, G.; Moulhérat, C.; Spantidaki, G. Archaeological textiles from Kerkyra. Arachne 2009, 3, 30-51.

86. Margariti, C.; Protopapas, S.; Allen, N.; Vishnyakov, V. Identification of purple dye from molluscs on an excavated textile by non-destructive analytical techniques. Dyes Pigment. 2013, 96, 774-780. [CrossRef]

87. Moulhérat, C.; Spantidaki, Y. A study of textile remains from the 5th century BC discovered in Kalyvia, Attica. In Ancient Textiles: Production, Craft and Society, Proceedings of the First International Conference on Ancient Textiles, Lund, Sweden, and Copenhagen, Denmark, 19-23 March 2003; Gillis, C., Nosch, M.-L., Eds.; Oxbow Books: Oxford, UK, 2007; pp. 163-166.

88. Spantidaki, Y.; Moulhérat, C. Greece. In Textiles and Textile Production in Europe from Prehistory to AD 400; Gleba, M., Mannering, U., Eds.; Oxbow Books: Oxford, UK, 2012; pp. 185-200.

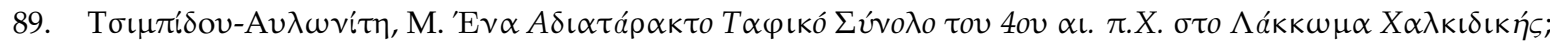

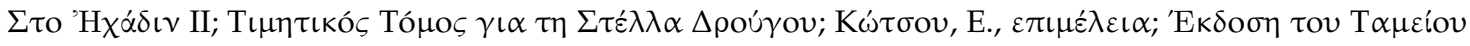

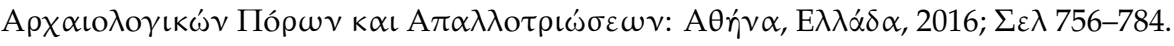

90. Daniels, V. Dye analysis on two fragments from Enkomi. Dyes Hist Archaeol 1985, 4, 15-18.

91. Gleba, M.; Vanden Berghe, I.; Cenciaioli, L. Purple for the masses? Shellfish purple-dyed textiles from the quarry workers' cemetery at Strozzacapponi (Perugia/Corciano), Italy. In Treasures from the Sea; Energen, H.L., Meo, F., Eds.; Oxbow Books: Oxford, UK, 2017; pp. 131-137.

92. Koren, Z.C. The Unprecedented Discovery of the Royal Purple Dye on the Two Thousand Year-Old Royal Masada Textile; The Textile Specialty Group Postprints; American Institute for Conservation of Historic and Artistic Works: Washington, DC, USA, 1997; Volume 7, pp. 23-34. 
93. Wouters, J.; Vanden Berghe, I.; Richard, G.; Breniaux, R.; Cardon, D. Dye analysis of selected textiles from three Roman sites in the eastern desert of Egypt: A hypothesis on the dyeing technology in Roman and Coptic Egypt. Dyes Hist. Archaeol. 2008, 21, 1-16.

94. Bruni, S.; Guglielmi, V.; Pozzi, F. Surface-enhanced Raman spectroscopy (SERS) on silver colloids for the identification of ancient textile dyes: Tyrian purple and madder. J. Raman Spectrosc. 2010, 41, 175-180. [CrossRef]

95. Doherty, B.; Nowik, W.; Miliani, C.; Clementi, C. Tyrian purple in archaeological textiles: DMF extraction and recrystallization for the Raman identification of precursors and derivatives. J. Raman Spectrosc. 2017, 48, 744-749. [CrossRef]

96. Karapanagiotis, I.; Sotiropoulou, S.; Vasileiadou, S.; Karagiannidou, E.; Mantzouris, D.; Tsiamyrtzis, P. Shellfish purple and gold threads from a late antique tomb excavated in Thessaloniki. Arachne 2018, 5, 64-77.

97. Wouters, J. A new method for the analysis of blue and purple dyes in textiles. Dyes Hist. Archaeol. 1992, 10, $17-21$.

98. Sato, M.; Sasaki, Y. Blue and purple dyestuffs used for ancient textiles. Dyes Hist. Archaeol. 2003, 19, $100-105$.

99. Michel, R.H.; Lazar, J.; McGovern, P.E. Indigoid dyes in Peruvian and Coptic textiles of the university museum of archaeology and anthropology. Archaeomaterials 1992, 6, 69-83.

100. Hofmann-de Keijzer, R.; Van Bommel, M.R.; De Keijzer, M. Coptic textiles: Dyes, dyeing techniques and dyestuff analysis of two textile fragments of the MAK Vienna. In Methods of Dating Ancient Textiles of the 1st Millennium AD from Egypt and Neighbouring Countries, Proceedings of the 4th Meeting of the Study Group 'Textiles from the Nile Valley', Antwerp, Belgium, 16-17 April 2005; De Moor, A., Fluck, C., Eds.; Lannoo Publishers: Tielt, Belgium, 2007; pp. 214-228.

101. Wouters, J. Dye analysis in a broad perspective: A study of 3rd to 10th century Coptic textiles from Belgian private collections. Dyes Hist. Archaeol. 1995, 13, 38-45.

102. Gulmini, M.; Idone, A.; Davit, P.; Moi, M.; Carrillo, M.; Ricci, C.; Dal Bello, F.; Borla, M.; Oliva, C.; Greco, C.; et al. The Coptic textiles of the Museo Egizio in Torino (Italy): A focus on dyes through a multi-technique approach. Archaeol. Anthropol. Sci. 2017, 9, 485-497. [CrossRef]

103. Hofmann-de Keizer, R.; Van Bommel, M. Dyestuff analysis of two textile fragments from late antiquity. Dyes Hist. Archaeol. 2008, 21, 17-25.

104. Walton, P. Shellfish purple in a Coptic textile. Dyes Hist. Archaeol. 1985, 4, 33-34.

105. Aceto, M.; Agostino, A.; Fenoglio, G.; Baraldi, P.; Zannini, P.; Hofmann, C.; Gamillscheg, E. First analytical evidences of precious colourants on Mediterranean illuminated manuscripts. Spectrochim. Acta A 2012, 95, 235-245. [CrossRef] [PubMed]

106. Aceto, M.; Idone, A.; Agostino, A.; Fenoglio, G.; Gulmini, M.; Baraldi, P.; Crivello, F. Non-invasive investigation on a VI century purple codex from Brescia, Italy. Spectrochim. Acta A 2014, 117, $34-41$. [CrossRef] [PubMed]

107. Porter, C.A.; Chiari, G.; Cavallo, A. The analysis of eight manuscripts and fragments from the fifth/sixth century to the twelfth century, with particular reference to the use of and identification of "real purple" in manuscripts. In Proceedings Art 2002: 7th International Conference on Non-Destructive Testing and Microanalysis for the Diagnostics and Conservation of the Cultural and Environmental Heritage; Van Grieken, R., Janssens, K., Van't dack, L., Meersman, G., Eds.; University of Antwerp: Antwerp, Belgium, 2002.

108. Bicchieri, M. The purple Codex Rossanensis: Spectroscopic characterisation and first evidence of the use of the elderberry lake in a sixth century manuscript. Environ. Sci. Pollut. Res. 2014, 21, 14146-14157. [CrossRef]

109. Andrikpolous, K.S.; Dannilia, S. Issues relating to the common origin of two Byzantine miniatures: In situ examination with Raman spectroscopy and optical microscopy. J. Raman Spectrosc. 2007, 38, 332-343.

110. Clementi, C.; Nowik, W.; Romani, A.; Cardon, D.; Trojanowicz, M.; Davantès, A.; Chaminade, P. Towards a semiquantitative non invasive characterisation of Tyrian purple dye composition: Convergence of UV-Visible reflectance spectroscopy and fast-high temperature-high performance liquid chromatography with photodiode array detection. Anal. Chim. Acta 2016, 926, 17-27. [CrossRef] [PubMed]

111. Verri, G.; de Fonjaudran, C.M.; Acocella, A.; Accorsi, G.; Comelli, D.; D'Andrea, C.; Nevin, A.; Zerbetto, F.; Saunders, D. An 'imperial radiation': Experimental and theoretical investigations of the photo-induced luminescence properties of 6,6'-dibromoindigo (Tyrian purple). Dyes Pigment. 2019, 160, 879-889. [CrossRef] 
112. Aceto, M.; Calà, E.; Agostino, A.; Fenoglio, G.; Gulmini, M.; Idone, A.; Porter, C.; Hofmann, C.; Rabitsch, S.; Denoël, C.; et al. Mythic dyes or mythic colour? New insight into the use of purple dyes on codices. Spectrochim. Acta A 2019, 215, 133-141. [CrossRef] [PubMed]

113. Katsifas, C.S.; Ignatiadou, D.; Zacharopoulou, A.; Kantiranis, N.; Karapanagiotis, I.; Zachariadis, G.A. Non-destructive $\mathrm{X}$-ray spectrometric and chromatographic analysis of metal containers and their contents from ancient Macedonia. Separations 2018, 5, 32. [CrossRef]

114. Benkendorff, K.; Rudd, R.; Nongmaithem, B.D.; Liu, L.; Edwards, V.; Avila, C.; Abbott, C.A. Are the traditional medical uses of Muricidae molluscs substantiated by their pharmacological properties and bioactive compounds? Mar. Drugs 2015, 13, 5237-5275. [CrossRef] [PubMed]

115. Nongmaithem, B.D.; Mouatt, P.; Smith, J.; Rudd, D.; Russell, M.; Sullivan, C.; Benkendorff, K. Volatile and bioactive compounds in opercula from Muricidae molluscs supports their use in ceremonial incense and traditional medicines. Sci. Rep. 2017, 7, 17404. [CrossRef] [PubMed]

116. Voultsiadou, E. Therapeutic properties and uses of marine invertebrates in the ancient Greek world and early Byzantium. J. Ethnopharmacol. 2010, 130, 237-247. [CrossRef] [PubMed]

117. Devièse, T.; Ribechini, E.; Baraldi, P.; Farago-Szekeres, B.; Duday, H.; Regert, M.; Colombini, M.P. First chemical evidence of royal purple as a material used, for funeral treatment discovered in a Gallo-Roman burial (Naintré, France, third century AD). Anal. Bioanal. Chem. 2011, 401, 1739-1748. [CrossRef] [PubMed]

118. Brysbaert, A. Murex uses in plaster features in the Aegean and eastern Mediterranean Bronze Age. Mediterr. Archaeol. Archaeom. 2007, 7, 29-51.

119. Brysbaert, A. Rotating angles in measuring the Aegean Bronze Age. The technology of bronze painted plaster from the Aegean and Eastern Mediterranean. In Measuring the Aegean Bronze Age, Proceedings of the 9th International Aegean Conference, New Haven, CT, USA, 18-21 April 2002; Foster, K.P., Laffineur, R., Eds.; Université de Liége and University of Texas at Austin: Liège, Belgium; Austin, TX, USA, 2003; pp. 167-178.

120. Brysbaert, A.; Perdikatsis, V. Bronze Age painted plaster from the Greek mainland: A comparative study of its technology by means of XRD analysis and optical microscopy techniques. In Proceedings of the 4th Symposium of the Hellenic Society for Archaeometry; Facorellis, Y., Zacharias, N., Polikreti, K., Eds.; National Hellenic Research Foundation: Athens, Greece, 2008; pp. 421-429.

121. Brysbaert, A.; Vandenabeele, P. Bronze Age painted plaster in Mycenaean Greece: A pilot study on the testing and application of micro-Raman spectroscopy. J. Raman Spectrosc. 2004, 35, 686-693. [CrossRef]

122. Koren, Z. New chemical insights into the ancient molluskan purple dyeing process. In Archaeological Chemistry VIII.; Armitage, R., Burton, J.H., Eds.; ACS Symposium Series; American Chemical Society: Washington, DC, USA, 2013; pp. 43-67.

123. Bogensperger, I. Purple and its various kinds in documentary papyri. In Textile Terminologies from the Orient to the Mediterranean and Europe, 1000 BC to 1000 AD.; Gaspa, S., Michel, C., Nosch, M.-L., Eds.; Univeristy of Nebraska and Zea Books: Lincoln, NE, USA, 2017; pp. 235-249.

124. Westlake, P.; Siozos, P.; Philippidis, A.; Apostolaki, C.; Derham, B.; Terlixi, A.; Perdikatsis, V.; Jones, R.; Anglos, R. Studying pigments on painted plaster in Minoan, Roman and Early Byzantine Crete. A multi-analytical technique approach. Anal. Bioanal. Chem. 2012, 402, 1413-1432. [CrossRef]

125. Brysbaert, A. Lapis lazuli in an enigmatic 'purple' pigment from a thirteenth-century BC Greek wall painting. Stud. Conserv. 2006, 51, 252-266. [CrossRef]

126. Mantzouris, D.; Karapanagiotis, I. Armenian cochineal (Porphyrophora hamelii) and purpurin-rich madder in ancient polychromy. Color. Technol. 2015, 131, 370-373. [CrossRef]

127. Fostiridou, A.; Karapanagiotis, I.; Vivdenko, S.; Lampakis, D.; Mantzouris, D.; Achilara, L.; Manoudis, P. Identification of pigments in Hellenistic and Roman funeral figurines. Archaeometry 2016, 58, 453-464. [CrossRef]

128. Sasaki, Y.; Matsubara, J.; Sasaki, K. Red dye analysis for historical textiles with multiple spectroscopic methods: An example for Coptic textiles in the Nara Silk Road Exchange Museum. In The Diversity of Dyes in History E Archaeology; Kirby, J., Ed.; Archetype Publications: London, UK, 2017; pp. 107-115.

129. Salvant, J.; Williams, J.; Ganio, M.; Casadio, F.; Daher, C.; Sutherland, K.; Monico, L.; Vanmeert, F.; De Meyer, S.; Janssens, K.; et al. A Roman Egyptian painting workshop: Technical investigation of the portraits from Tebtunis, Egypt. Archaeometry 2018, 60, 815-833. [CrossRef]

130. Karadag, R.; Torgan, E. Advantages and importance of natural dyes in the restoration of textile cultural heritage. Int. J. Conserv. Sci. 2016, 7, 357-366. 
131. Aceto, M.; Agostino, A.; Fenoglio, G.; Idone, A.; Crivello, F.; Griesser, M.; Kirchweger, F.; Uhlir, K.; Puyo, P.R. Analytical investigations on the Coronation Gospels manuscript. Spectrochim. Acta A 2017, 171, $213-221$. [CrossRef] [PubMed]

132. Denoël, C.; Puyo, P.R.; Brunet, A.-M.; Siloe, N.P. Illuminating the Carolingian era: New discoveries as a result of scientific analyses. Herit. Sci. 2018, 6, 28. [CrossRef]

133. Melo, M.J.; Nabais, P.; Guimarães, M.; Araújo, R.; Castro, R.; Oliveira, M.C.; Whitworth, I. Organic dyes in illuminated manuscripts: A unique cultural and historic record. Philos. Trans. A Math. Phys. Eng. Sci. 2016, 374, 20160050. [CrossRef] [PubMed]

134. Padden, A.N.; Dillon, V.M.; John, P.; Edmonds, J.; Collins, M.D.; Alvarez, N. Clostridium used in mediaeval dyeing. Nature 1998, 396, 225. [CrossRef]

135. Koudous, I.; Kunz, W.; Strube, J. Panorama of sustainable solvents for green extraction processes. In Green Extraction of Natural Products; Chemat, F., Strube, J., Eds.; Wiley-VCH: Weinheim, Germany, 2015; pp. 173-236.

136. Hansen, C.M. Hansen Solubility Parameters: A User's Handbook, 2nd ed.; CRC Press: Boca Raton, FL, USA, 2007.

(C) 2019 by the author. Licensee MDPI, Basel, Switzerland. This article is an open access article distributed under the terms and conditions of the Creative Commons Attribution (CC BY) license (http://creativecommons.org/licenses/by/4.0/). 